Pratt II Conference

"Petroleum Provinces of the $21^{\text {st }}$ Century"

January 12-15, 2000

San Diego, California

\title{
Future Petroliferous Provinces of Venezuela
}

\author{
F. E. AUDEMARD \\ I. C. SERRANO \\ PDVSA Exploration and Production \\ Caracas, Venezuela
}

Recent regional studies have indicated that a resource potential greater than $40 \mathrm{BBOE}$ remains to be found in Venezuela. Evidence for new petroliferous provinces that hold this potential will be presented in this paper.

Venezuela is a showcase for the exceptional foredeep basins of northern South America, together with outstanding oil source rocks and reservoirs next to unconformities within these foredeeps.

In the southwest of the country, sandstones above and below the foredeep unconformity, form potential strat-traps, a possible western extension of the prolific Eastern Venezuelan Basin (EVB). This would be an exceptional area to evaluate weathered/fractured basement plus Jurassic fills of half grabens located below the passive margin sequence. Also in the west, the northern and southern flanks of the Mérida Andes, with 70 oil seeps, remains virtually unexplored.

Of importance are: the 25.000 feet of mostly Neogene sediments offshore the Orinoco Delta where five wells have tested 5 TCF and condensate; a 100 mile long diapir wall in the middle of the EVB with three major fields, and the 70 mile long downthrown Anaco inverted structure, tested in two localities. The mountain fronts to the north are being drilled to evaluate the northern extension of the giant Furrial trend and a new thrust play to the northwest.

The $150.000 \mathrm{sq} \mathrm{km}$ offshore area has only 50 wildcats, most drilled as tests for conventional traps; however, complex strike-slip structures, strat-traps and deep water plays could exist. Oil seeps and shows in wells indicate this is an oil prone basin. 


\section{INTRODUCTION}

Many explorers have proposed ideas that gave way to the discovery of giant oil and gas fields in Venezuela. Some did not have the chance to visualize the real size of the giant traps due to acreage limitations or the incipient control on the key parameters involved in the definition of the reservoirs. Most of the giant Venezuelan fields known today were discovered prior 1960 (Miller et. al., 1958; Smith, 1956; Salvador and Stainforth, 1968; Martinez, 1995; Mencher, et. al., 1953).

A new wave of students concerning this subject has focused the search upon this size of trap and the play where they are inserted. The large cross-sections put together and recent studies (Stephan, 1982; James, 1985; Aymard; et. al. 1990; Audemard, 1991; Lugo, 1991; Erlich and Barrett, 1992; Duval, et. al., 1994; Di Croce, 1995; Parnaud, et. al., 1995; Hung, 1997; Ysaccis, 1997) have provided new insights that allow us to propose some of the additional ideas released here, using eleven examples.

In spite of an exploration and production history that started in the nineteenth century in Venezuela, mainly around oil seeps, seventy five percent of the sedimentary basins still remain underdrilled. This means that of a total of $500.000 \mathrm{~km}^{2}, 375.000 \mathrm{~km}^{2}$ could still hold undiscovered accumulations (Figure 1). On top of this, at least $20 \%$ of the areas under production have not been drilled down to economic "basement".

Venezuela's cumulative oil production is close to $50 \mathrm{MMMB}$ and oil proven reserves totalize 72 MMMB; cumulative gas production is $69 \mathrm{MMMMPC}$ and gas proven reserves are 147 MMMMPC. At least 30 giant oil fields and 5 giant gas fields have been located. The largest single accumulation known to date is on the rim of the most prolific foredeep basin, where over 1 trillion barrels of oil are in place. The magnitude of these numbers serves to illustrate Venezuela's hydrocarbon richness.

Despite these figures and their magnitudes, explorationists continue their search for new hydrocarbons in areas with potential for giant fields with reserves larger than $500 \mathrm{MMB}$ of oil or $3 \mathrm{TCF}$ of gas. In this paper, evidences of these future petroliferous provinces are shown using reflection seismic profiles (Figure 1).

As Wallace Pratt used to say "oil is found in the minds of men". 


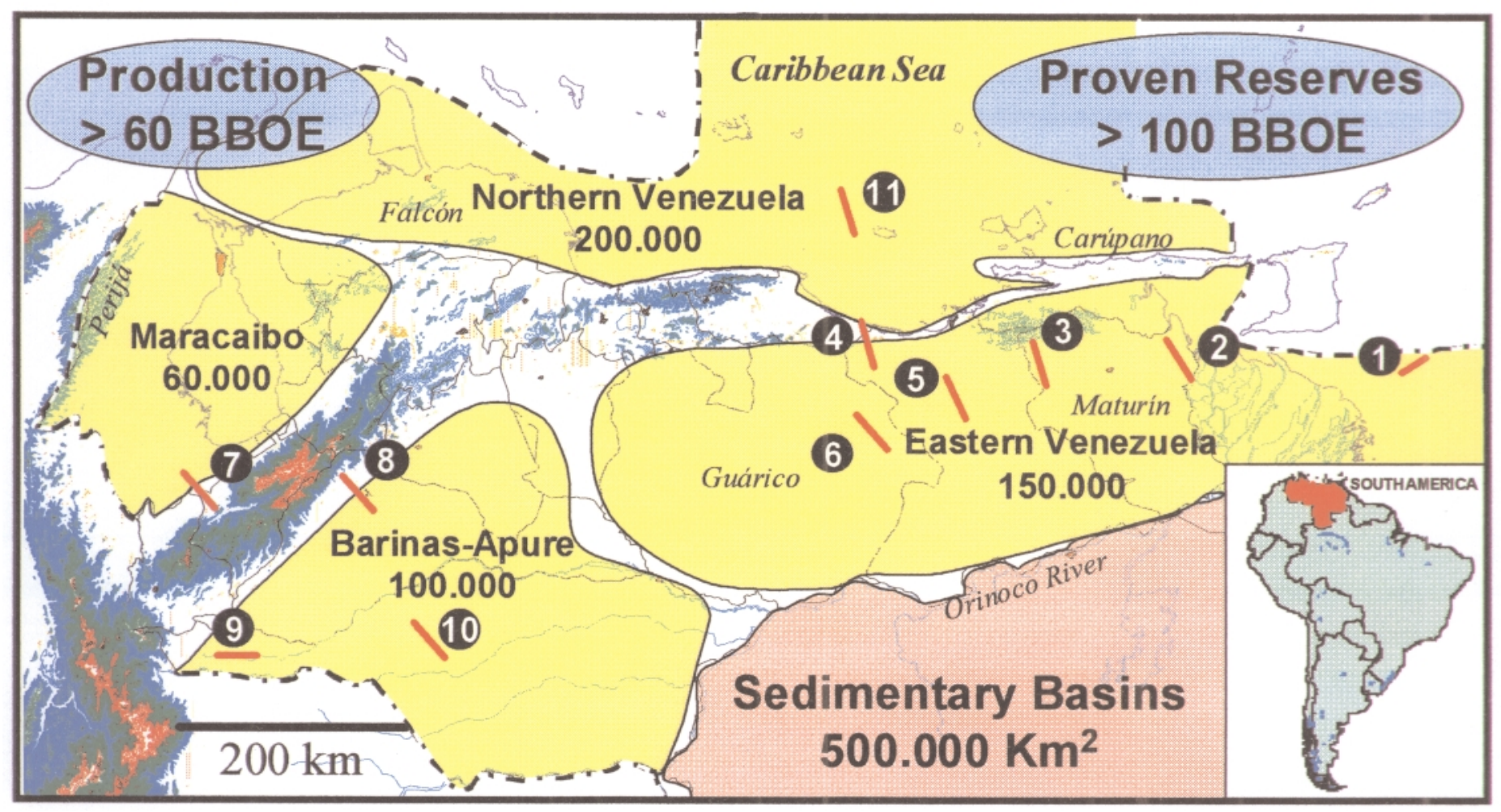

Figure 1. The areas shown are the major onshore and offshore basins; numbers correspond to the areal extent of the basins in $\mathrm{km}^{2}$. Cumulative production and proven reserves of Venezuela are indicated in equivalent barrels. Sesimic lines used to illustrate Future Petroliferous Provinces are in red and referred to numbers. 


\section{DISCUSSION}

\section{ACTIVE AND PASSIVE MARGINS EVOLUTION}

In order to illustrate part of the present potential of the Venezuelan sedimentary basins we will address this from two very distinctive perspectives. One is to deal with the configuration and stacking of the different basins that prevailed during the Phanerozoic and the second is devoted to the major source rocks feeding the petroleum systems active during the evolution of these basins.

Most of the students of this problem are concerned with the Late Cretaceous source beds as well as the evolution of northern South America since the deposition of these rich intervals. Then the scheme in "vogue" is one where the broad passive margin containing these source-rocks is progressively matured due to flexural loading and subsequent emplacement of a foredeep related to the interaction between the SouthAmerican and Caribbean Plates.

Figure 2 shows this evolutionary path across northern South America. An eastward migration of the foredeeps occurs and is illustrated for the units deposited since Late Cretaceous (western Venezuela) to Recent (eastern Venezuela, near the Orinoco Delta). This diagram, modified from Audemard \& Lugo,1996, highlights a dual passive margin setting (Tethys \& Atlantic). This division has been considered because in the Venezuelan literature, the oldest rocks associated with the Mesozoic passive margin are Barremian in age. However, in Trinidad and Colombia, older Cretaceous and Jurassic rocks are part of the succession, where no major break in sedimentation has been reported. This fact could be explained by means of interpreting the stack of sediments and metasediments observed along the Coastal Ranges in Northern Venezuela. They would be part of the distal deep, and slope sediments of a passive margin edifice and of the oceanic crust (ophiolites) thrusted as portions of a folded belt developed from the frontal segments of the passive margin. This dual configuration is deduced from a major angular unconformity, probably induced by salt tectonics, well developed and visible on seismic profiles in offshore French Guiana. The nature of the unconformity is probably related to the salt, but it could well be also related to the shift from the Tethys to the Atlantic opening in this portion of the planet. This implies that we are in pursuit of an unconformity, which becomes a major migration pathway across the Lower Cretaceous strata.

On the other hand, in a classic or idealized foredeep scheme as shown in Figure 3 (Bally, 1989) we would need to consider a second break-up unconformity which will facilitate oil migration down section. It is possible to interpret the existence of other source rocks, older than the Late Cretaceous always invoked. These additional potential source rocks might be distributed somewhat different from La Luna-Querecual pattern due to a slight change in the passive margin configuration.

These potential new hydrocarbon sources can be inferred from very distinct points of view. The amount of oil "in situ" in the Orinoco Oil Belt does not satisfy the mass balance for the Late Cretaceous source reported. A second marine source is needed, but as the oil trapped in the Orinoco Oil Belt has certainly arrived early, then, a deeper, distal source is a viable option. A second aspect has to do with the fact that the amount of oil in place forces the consideration that at least one third of the oil leaving the source beds has been biodegraded, which means that the system needs to have more oil available.

The diagrams of Figures 4 and 5 allow us to postulate a third option which, in a very favorable environment, would be a new avenue for the explorationist, by means of overlaying the idealized foredeep model. The Tertiary foredeep does not directly encroach upon the Precambrian Shield and is floating on top of the Late Paleozoic Foredeep. This array is presented in Figure 4 where the geometric configurations of the elements have been honored. The leading edge of the Paleozoic folded belt (Figure 4) reached a position closer to the shield relative to that of the Tertiary. As a consequence, a narrower elongated Paleozoic foreland basin is still preserved at a very shallow depth. The frontal folded structures that have been partially eroded remain unexplored. No effort has been devoted to explore all the units under the Cretaceous passive margin unconformity, despite indications of oil impregnations in some cores of Paleozoic Rocks. 


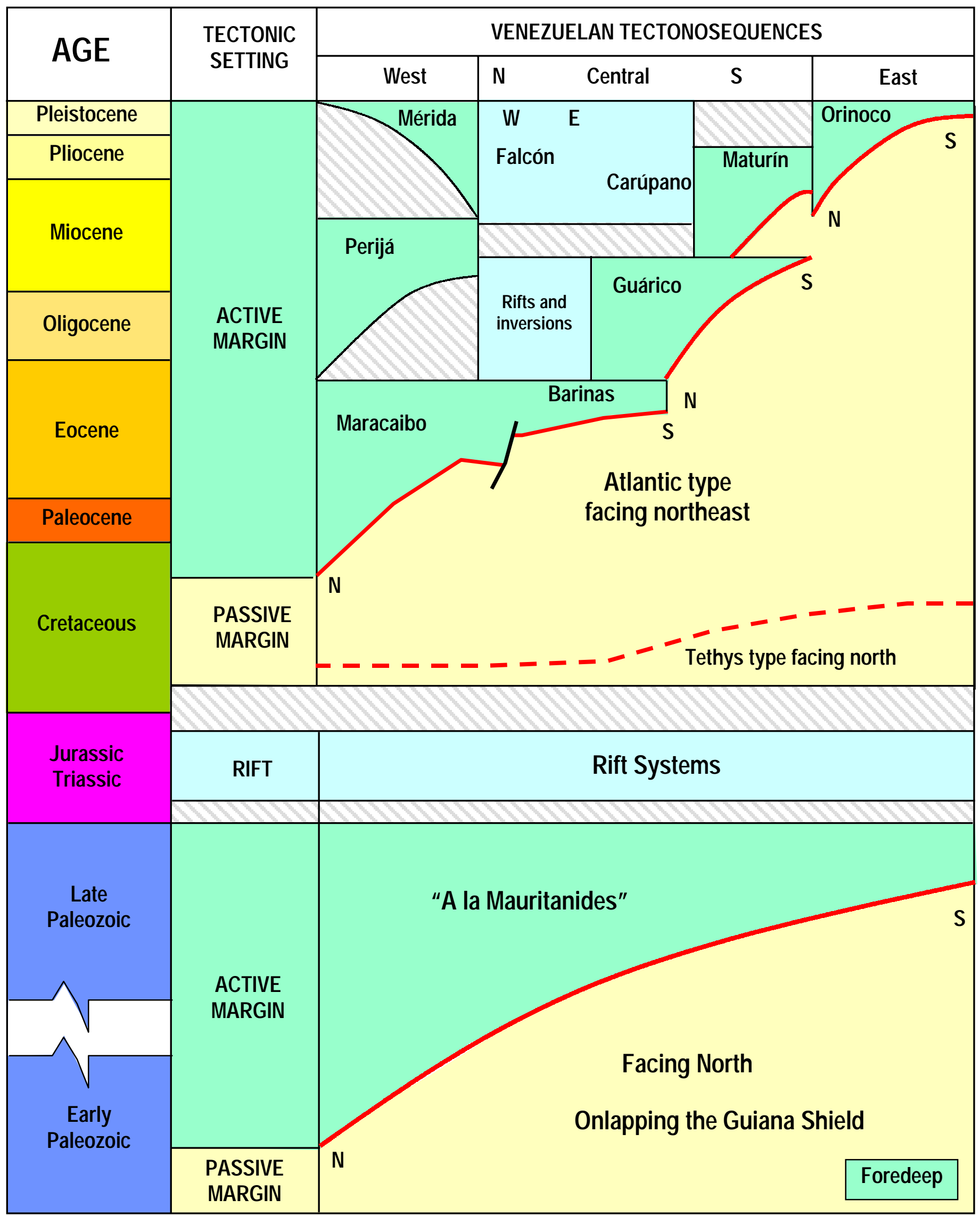


Figure 2 (page 5). The diagram shows various settings; a combination of a Paleozoic passive and active margin, and two Mesozoic passive margins (Tethys and Atlantic) superimposed by a Late Cretaceous to Recent eastwards foredeep migration (Modified from Audemard and Lugo, 1996; Lugo and Audemard, 1996).

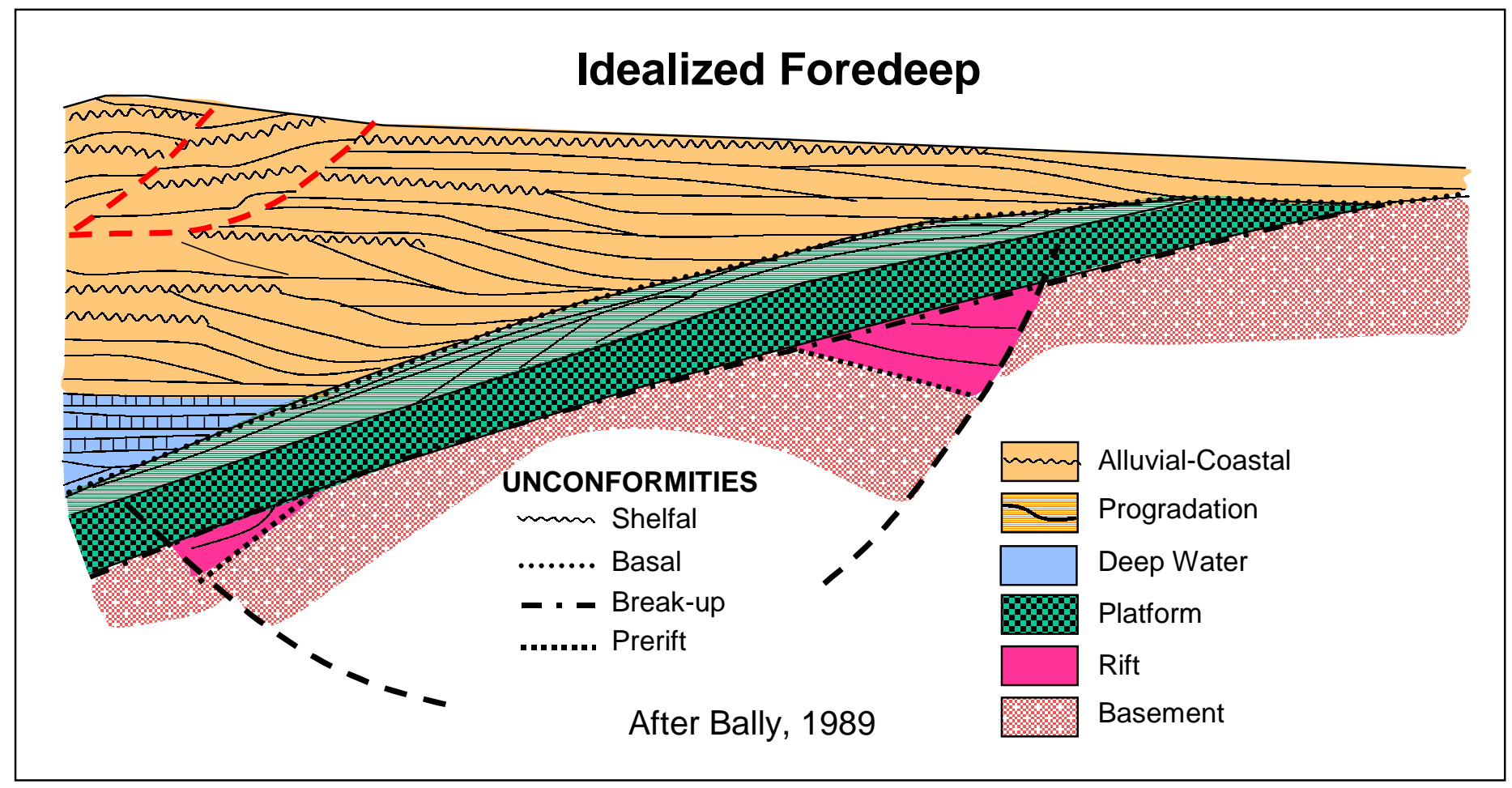

Figure 3. Idealized scheme of a foredeep.

A more enthusiastic idea would be to consider the Silurian-Devonian shales as tentative oil source beds for this Paleozoic folded belt. These rocks are exposed in window slates in the Merida Andes and in Northern Perija. This implies that they belong to an Early Paleozoic passive margin and their thicknesses are equivalent to the Cretaceous units reported as very prolific source beds.

\section{VENEZUELA'S PETROLEUM SYSTEMS}

One of the reasons Venezuela has a large aereal hydrocarbon richness is because of the number of source rocks present along the sedimentary column and across the country (Audemard, et. al., 1997). It also happens, that most of these source rocks were buried and matured through time due to the overlapping development of foredeeps and rift basins.

Although the most prolific oil and gas source rocks identified so far in Venezuela were deposited during the Upper Cretaceous (Hedberg, 1931), on a passive margin developed as a consequence of the opening of the Atlantic Sea, many other important Cretaceous and Tertiary source rocks are present and have been characterized by different authors.

The Upper Cretaceous source rocks (La Luna Querecual Formations) are mainly marine type II, with minor amounts of type III, algae rich calcareous shales and shales extended during this time across the northern part of Venezuela. Their original total organic carbon content was as high as $10 \%$, specially in La 
Luna Formation, and their thicknesses vary from more than $195 \mathrm{~m}$ (650 feet) in the southwest of Venezuela (Blaser and White, 1984) to120 m (400 feet) in the east. Hydrogen Index can reach up to $500 \mathrm{mg} / \mathrm{gr}$ of TOC.

In the Maracaibo Basin, similar to La Luna Formation, the Lower Cretaceous Machiques Member with a significant thickness of more than $50 \mathrm{~m}$ (150 feet) is present towards the Perija Mountain Front and Paleocene Eocene coals and carbonaceous shales deposited in the northwest of the Andes have generated hydrocarbons, oil and gas, later encountered within Tertiary reservoirs. Eastwards of this basin, Lower Eocene shales contain enough TOC \% to generate hydrocarbons, although this has not been demonstrated yet. In the Barinas Apure Basin, the Upper Cretaceous source rocks can account for those hydrocarbons already found.

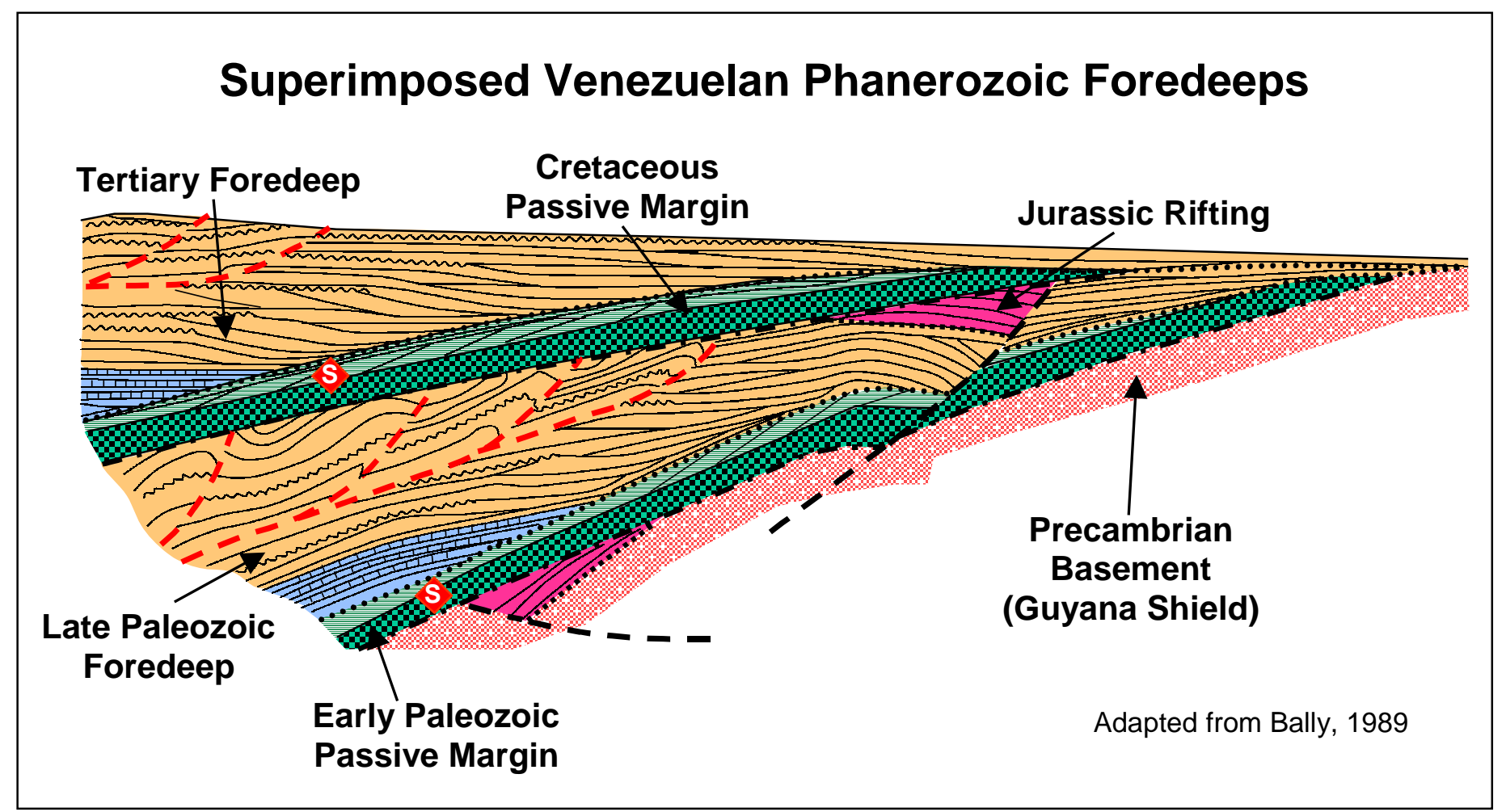

Figure 4. Idealized cross-section showing the Paleozoic and Mesozoic-Cenozoic passive and active margins relationships. $\mathrm{S}=$ source rocks. 


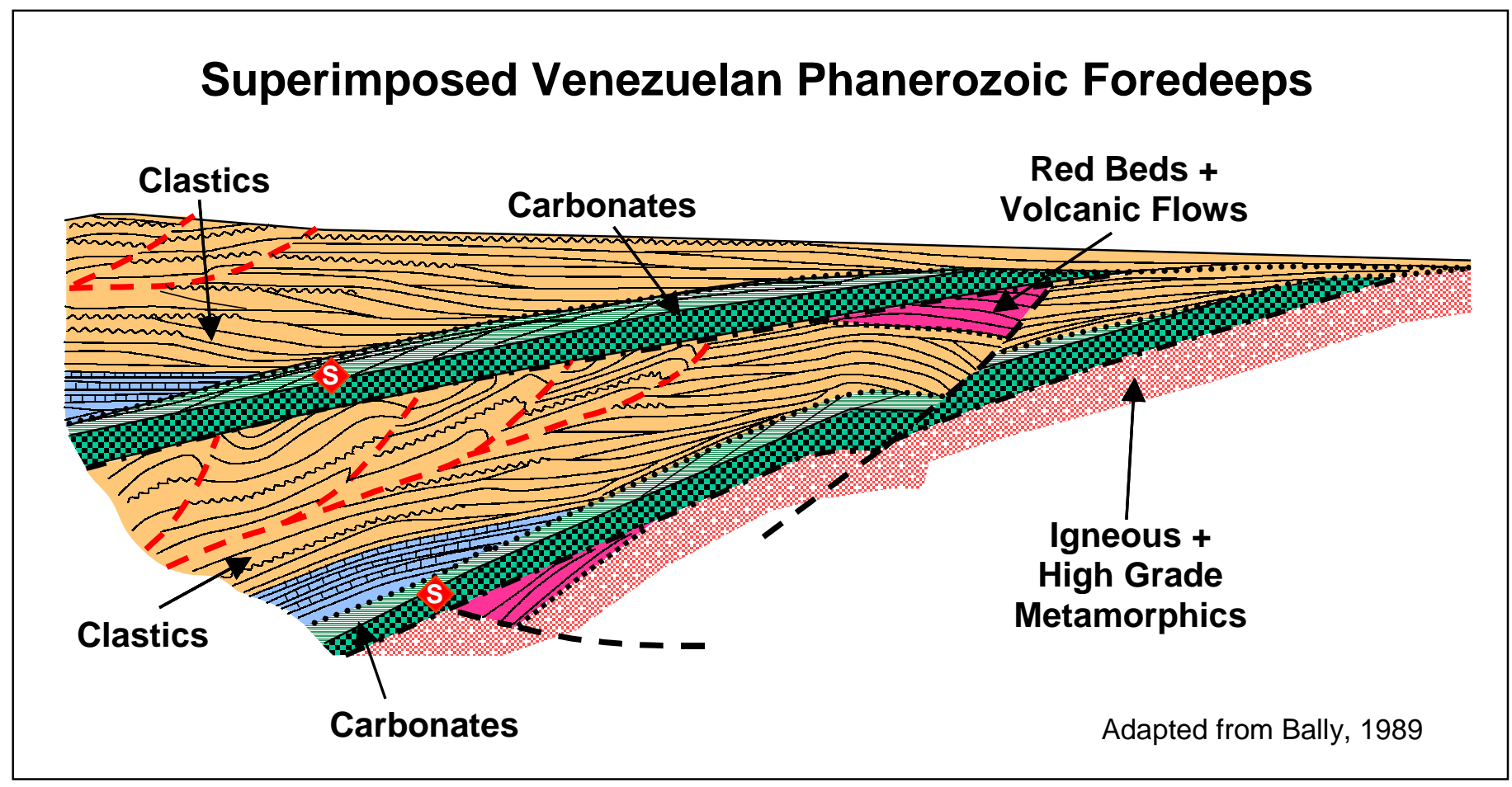

Figure 5. Same as the cross-section of Figure 4 but indicating lithological relationships. S = source rocks.

Across the Eastern Venezuelan Basin, besides the Upper Cretaceous source rocks, Oligocene and Miocene type III source rocks have been measured. They consist of marine to terrestrial shales and coals, with thicknesses that vary from $30 \mathrm{~m}$ (150 feet) to $100 \mathrm{~m}$ (300 feet), and TOC as high as $11 \%$.

Figure 6 shows the possible extension of generating areas through time of Upper Cretaceous source rocks. Hydrocarbon generation and expulsion started during the Middle Eocene in the west and it is still going on in the east, along the Orinoco and Maturin foredeeps, and the Caribbean Plate accretionary prism. Only in the south, towards the Guyana Shield, possible source rocks are inmature. Nevertheless, regional dip and migration along coastal and deltaic sandstones and extensive unconformities favored these areas in which the huge reserves of the Orinoco Oil Belt have been found (Audemard, et. al., 1993). In this figure, it has been indicated a tentative extension of the Paleozoic generating areas.

Different from onshore, in the offshore basins and Falcón the main systems consist of Tertiary, Eocene to Middle Miocene, type II-III shaly source rocks, able to generate oil and gas (Boesi and Goddard, 1991). These were deposited within rift basins during the development of the active margin and matured since then until the present (Figure 7).

Unknown Triassic and Jurassic source rocks might also be present (Cocinas trough Goajira Peninsula), due to the deposition of marine lacustrine shales in restricted basins, like the ones described in Central Venezuela (Bartok, 1993). And as mentioned in the previous discussion, Silurian to Devonian source rocks deposited during the development of the Paleozoic passive margin may be responsible for the oil staining in Pre-Cretaceous rocks.

How much oil has been retained in the many traps formed along the passive and active margin during their evolution is a critical issue to the understanding of the large petroliferous provinces. 


\section{FUTURE PETROLIFEROUS PROVINCES}

Eleven different plays have been selected, so as, to offer a flavor of the search for new oil across the traditional Venezuelan Basins. They will be presented from east to west. Many of the most relevant trap styles and potential source locations will be highlighted on the seismic profiles as well as some of the evidences found in wells and outcrops.

\section{DELTA PLATFORM (1)}

Area $\left(\mathrm{km}^{2}\right)$

Wildcats drilled

Number of Discoveries

Type of Traps

Main Reservoirs

Hydrocarbon Systems

Hydrocarbon Types

Critical Aspects
3000-5000 (Figure 8)

5 in Venezuela, more than 20 in Trinidad

3 (Tajali, Loran, Cocuina) in Venezuela

12 fields in Trinidad

Hanging wall of normal faulted blocks, Tilted blocks

Cretaceous continental sandstones and deep-water Plio-Pleistocene sandstones

Upper Cretaceous shales

Miocene shales

Gas, condensates and minor amounts of liquids at depths less than 13000 feet

Reservoir distribution 


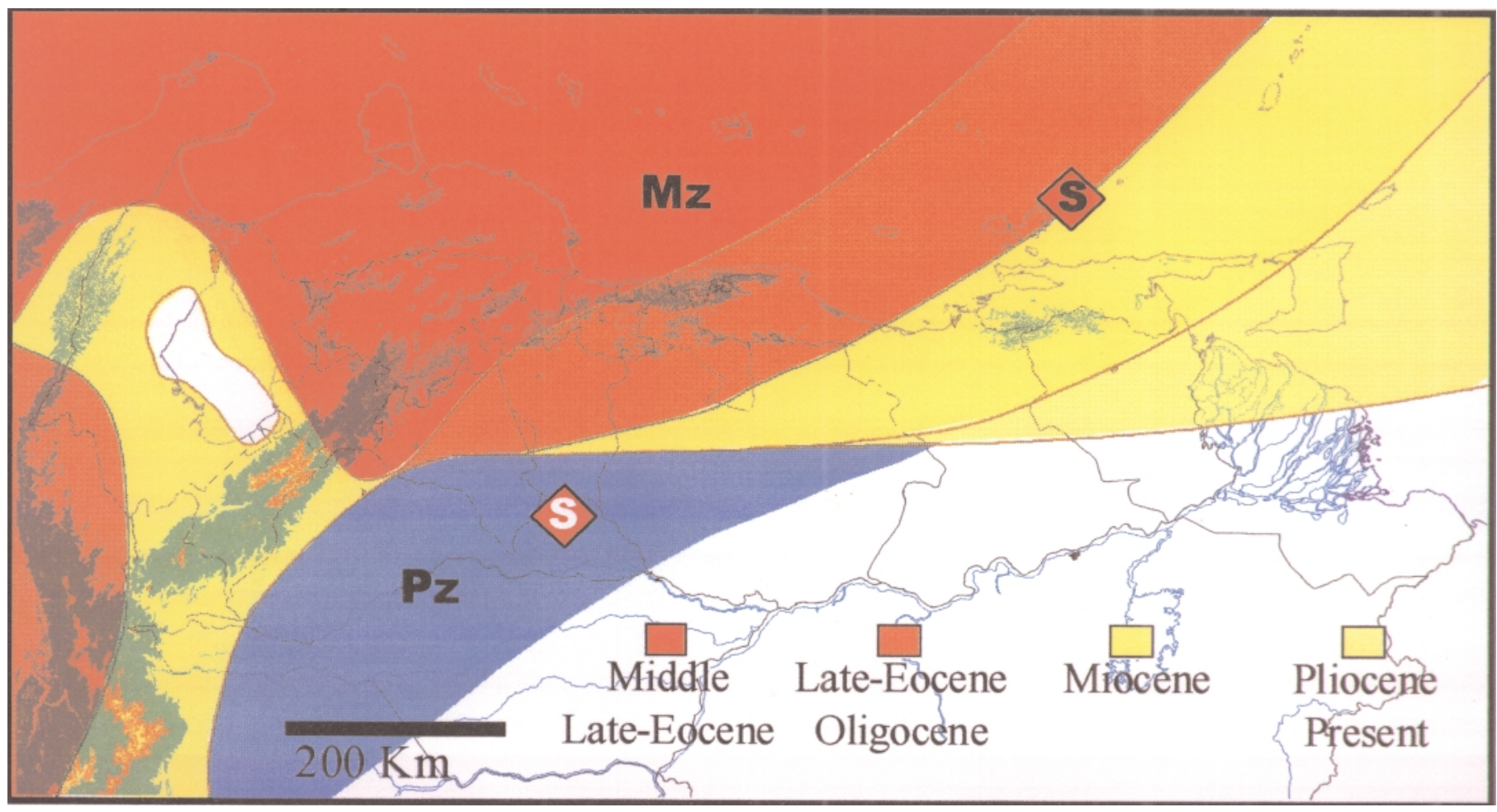

Figure 6. Upper Cretaceous source rocks and their simplified Eocene to Present day generating areas. (Erlich and Barrett, 1992; Audemard, et al., 1993; Talukdar, et. al., 1986; Talukdar and Marcano, 1994; Chigne and Hernandez, 1993; Parnaud, et al., 1995). Also notice tentative extent of Paleozoic generating areas.

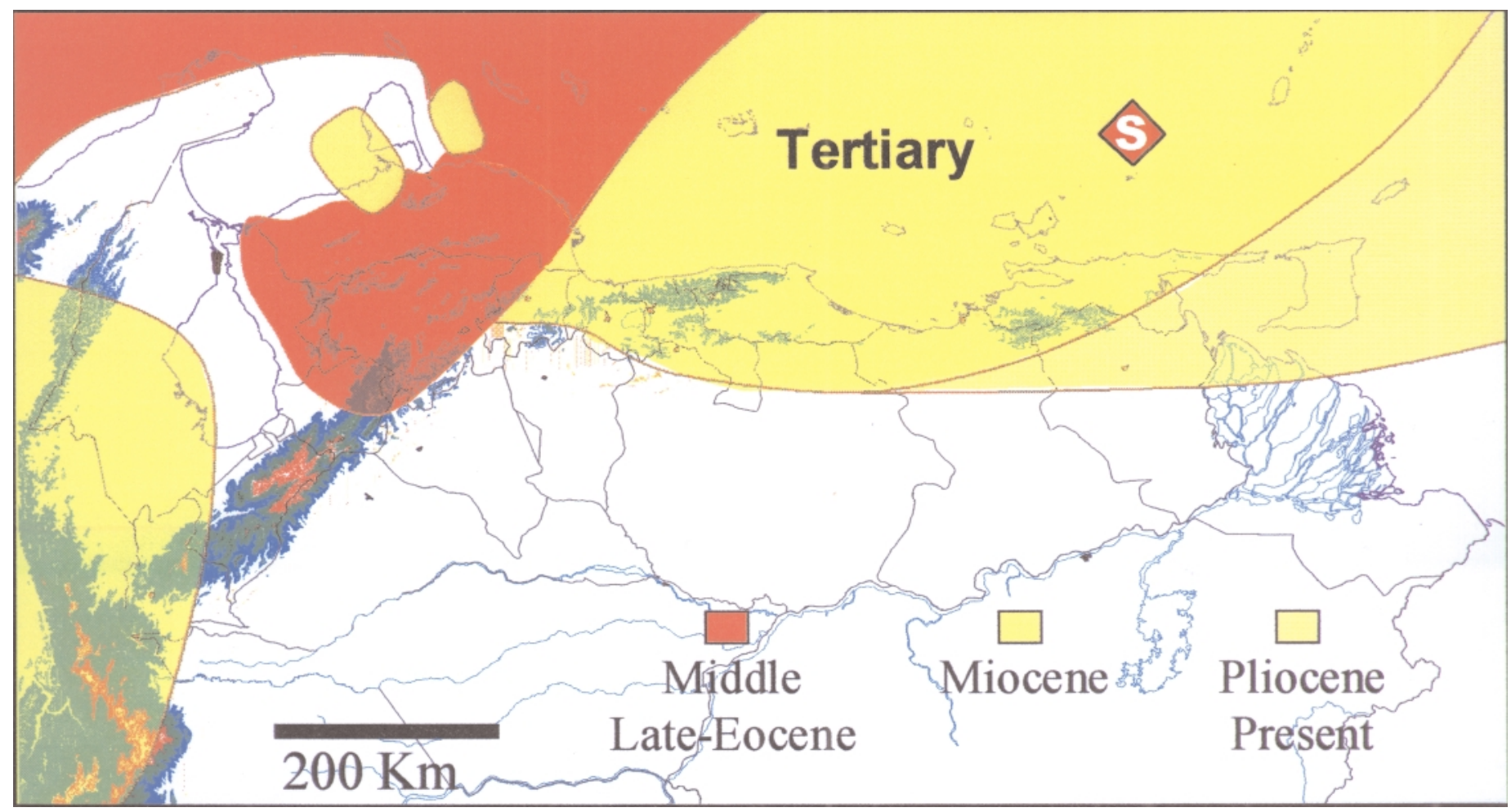

Figure 7. Tertiary source rocks and their simplified Eocene to Present day generating areas. 
This province is constrained to the most recent portion in the evolution of the foredeep. It is located offshore, close to the actual Orinoco Delta slope break, where many northwest trending normal faults occurred (Figure 9). Each of the upthrown sides of these normal faulted blocks is a potential trap, with more than $7500 \mathrm{~m}$ (25000 feet) of Miocene and Plio-Pleistocene sandstones and shales. Faulting dies out above the condensed Paleogene section and some can also cut through the Cretaceous source rocks and communicate them with the reservoirs. Fault plane tips are so close to the Cretaceous top that they can serve as hydrocarbon conduits. Present day oil and gas generation and expulsion from Miocene and Cretaceous source rocks favor this area, where, several fields have already been found in Trinidad. A discussion of the geological setting of this province can be found in Di Croce Ph.D. Thesis, 1995.

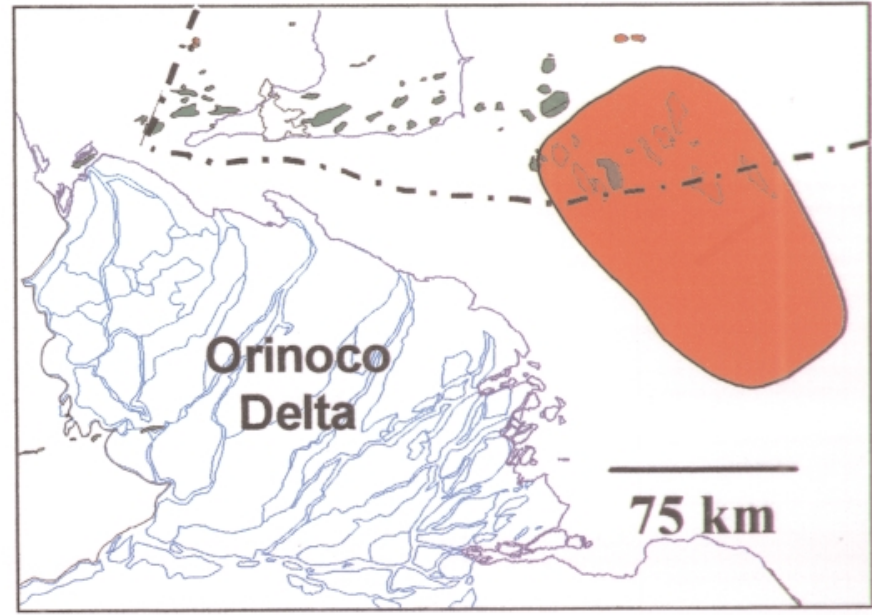

Figure 8. Location of Seismic Line (1)

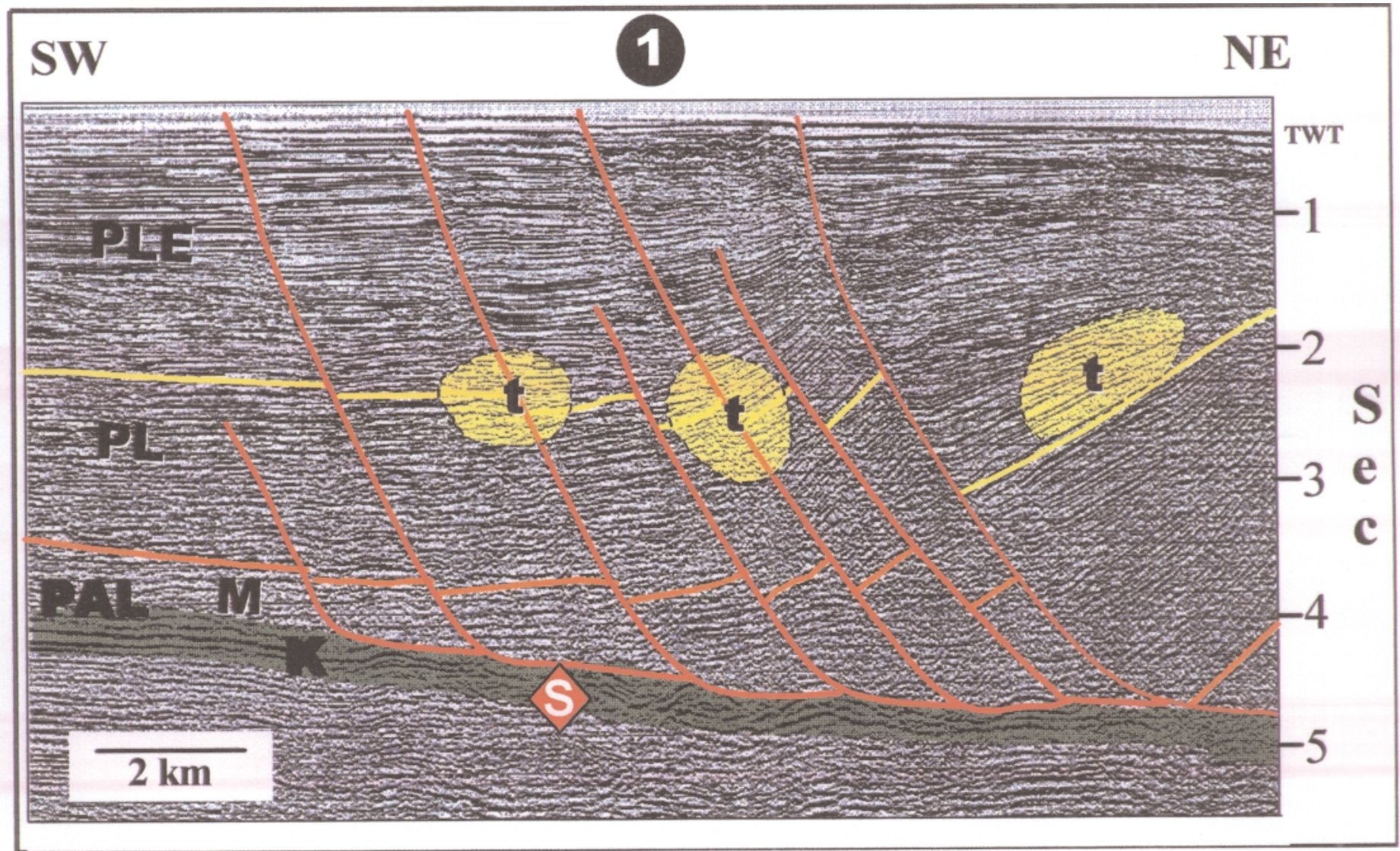

Figure 9. Normal faults cutting a thick Tertiary section create the trapping mechanism. Each upthrown side of a normal fault is a potential trap.

Faults cut from surface to top of the Paleogene section, sometimes up to the Cretaceous source rocks. $\mathrm{K}=$ Cretaceous; $\mathrm{PAL}=$ Paleogene; $\mathrm{M}=$ Miocene; $\mathrm{PL}=\mathrm{Pliocene}$; $\mathrm{PLE}=$ Pleistocene; $\mathrm{S}=$ Source rock; $\mathrm{t}=$ Trap. 


\section{DIAPIR BELT (2)}

Area $\left(\mathrm{km}^{2}\right)$ :

Wildcats drilled

Number of Discoveries

Type of Traps

Main Reservoirs

Hydrocarbon System

Hydrocarbon Types

Critical Aspects
1500-3000 (Figure 10)

None

1 (Pedernales Field) in Venezuela

1 (El Soldado Field) in Trinidad

Onlaps on diapir wall

Reverse faulted blocks

Miocene to Pliocene sandstones

Upper Cretaceous shales

Miocene shales

Light oil and associated gas

Significant hydrocarbon charge

A belt of mud diapirs with two ridges extends parallel to the mountain front of the Eastern Interior Mountain Range (Figure 11). On both sides of these ridges onlapping Miocene and Pliocene Sandstones form traps that have been successfully proven in two fields, Pedernales in Venezuela and El Soldado in Trinidad. Since 1950, Hedberg announced the presence of mud volcanoes and associated seeps along this belt. The shales that form the ridges were deposited during the Lower Miocene and compression since the Pliocene activated mud remobilization. A Miocene to Recent phase of generation and expulsion favors the presence of hydrocarbons in these traps. Although significant hydrocarbon charge is a critical issue, oil seeps associated with the mud volcanoes indicate leaking from these traps.

Another type of traps associated to this setting are the reverse faults caused by the collapse or normal faulting between the two ridges. Each of these blocks can have a hydrocarbon accumulation.

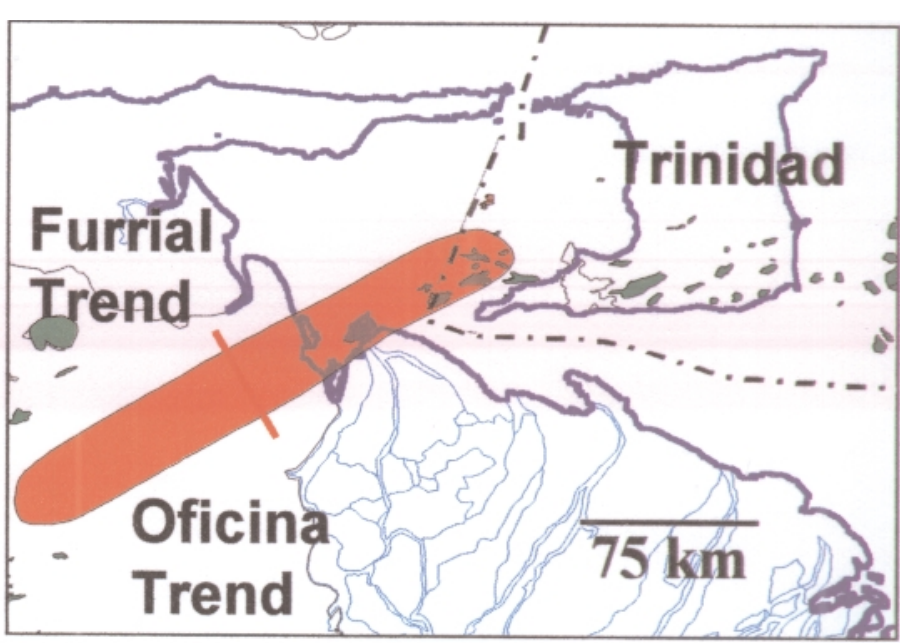

Figure 10. Location of Seismic Line (2)

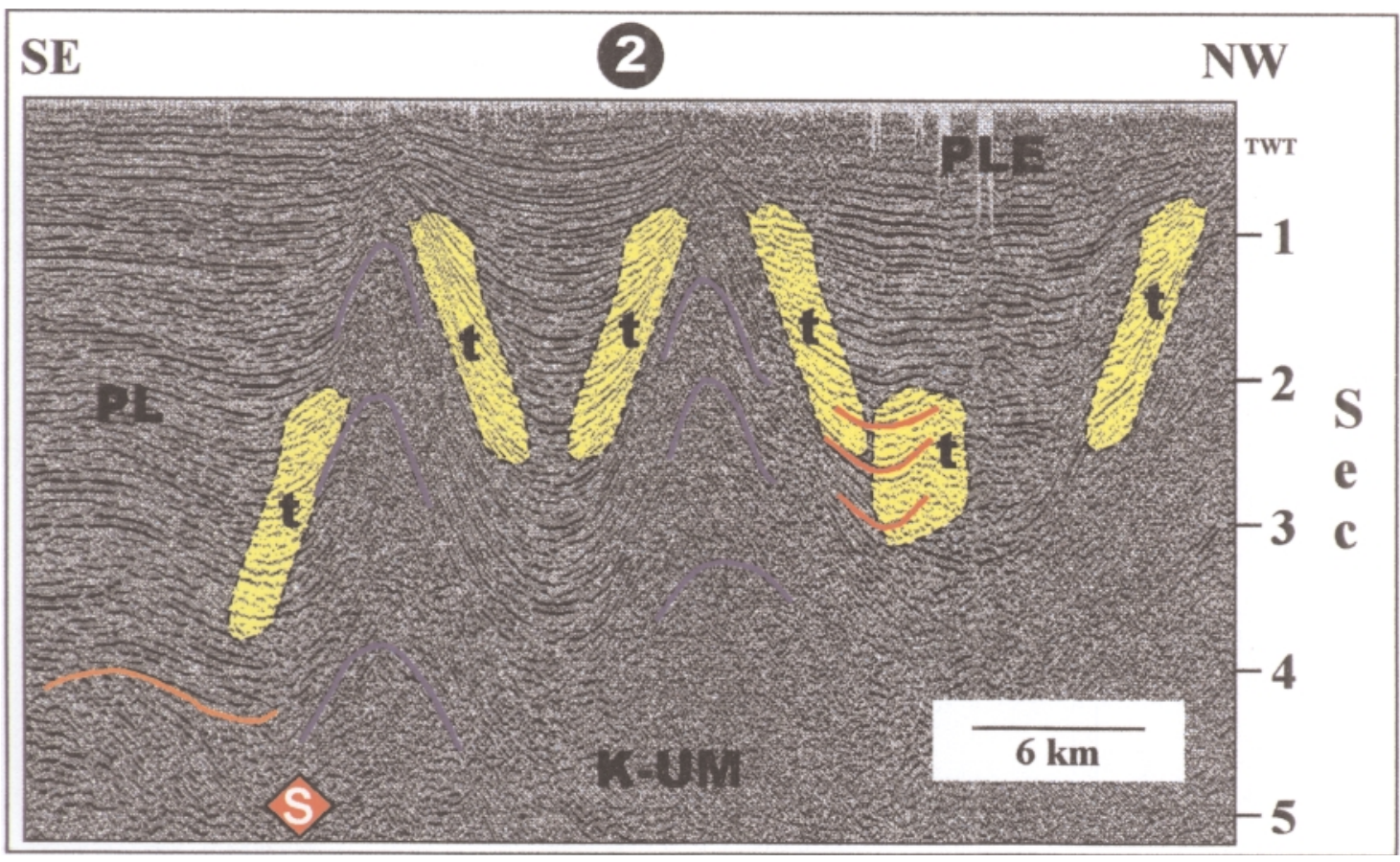

Figure 11. A muddiapir belt with two ridges. Onlaps and collapse reverse faults create the traps. K$\mathrm{UM}=$ Cretaceous to Upper Miocene; $\mathrm{PL}=$ Pliocene; PLE=Pleistocene; $\mathrm{S}=$ Source rock; $\mathrm{t}=$ Trap; Red lines $=$ Reverse faults. 


\section{SOUTHERN EASTERN MOUNTAIN RANGE (3)}

Area $\left(\mathrm{km}^{2}\right)$ :

Wildcats drilled

Number of Discoveries

Type of Traps

Main Reservoirs

Hydrocarbon System

Hydrocarbon Types

Critical Aspects
3000-5000 (Figure 12)

None

None. The Giant Furrial trend is downdip

Thrusts

Cretaceous to Miocene Sandstones

Upper Cretaceous shales

Miocene shales

Gas, condensates and light oil

Reservoir integrity

This region represents the northern extension of the Furrial trend (Figure 13). The style, size and distribution of the anticlinal structures are part of the transition to the hinterlands of the Serrania del Interior in the segment where no metamorphic rocks have been sighted to date. The advent of new technology (seismic imaging and drilling) allows the explorationists to investigate this proven petroliferous system.

All of these structures located north of the Furrial trend would tend to increase the probability of finding options with higher GOR ratio compared to the tested area.

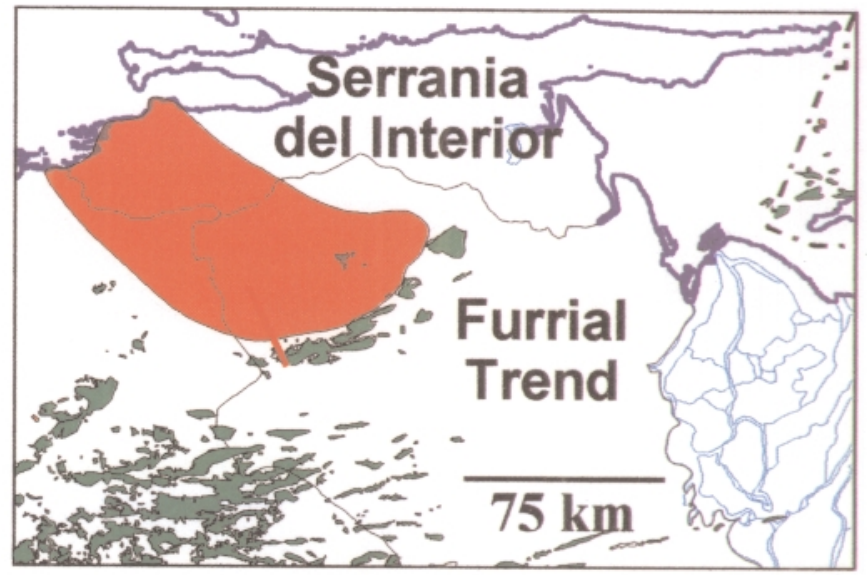

Figure 12. Location of Seismic Line (3)

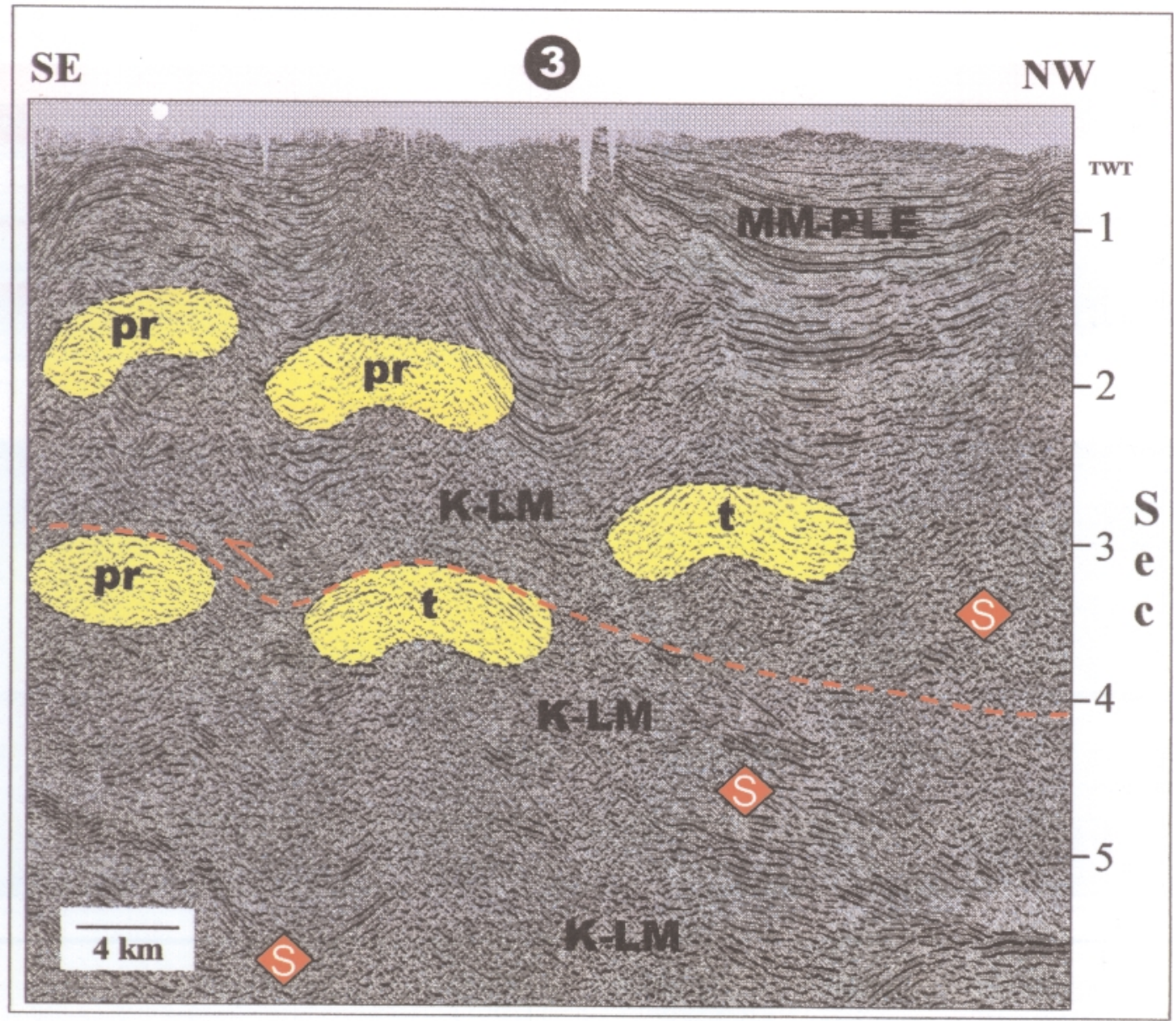

Figure 13. A Cretaceous to Lower Miocene section containing source rocks and reservoirs is repeated three times due to the occurrence of two decollement zones. Anticlines associated with thrusting of the two lowermost sections remain underexplored and also thrust to the north of the Furrial trend, where a seimic survey is being currently shot. K-LM= Cretaceous

Lower Miocene; MM-PLE

$=$ Middle Miocene to Pleistocene; $\mathrm{S}=$ Source; $\mathrm{t}$ $=$ Trap; $\mathrm{pr}=$ Proven Reservoir; Red arrow = Decollement zone. 


\section{SOUTHERN CENTRAL MOUNTAIN RANGE (4)}

Area $\left(\mathrm{km}^{2}\right)$ :

Wildcats drilled

Type of Traps

Main Reservoirs

Hydrocarbon Systems

Hydrocarbon Types

Critical Aspects
5000-7000 (Figure 14)

None

Subthrusting anticlines

Cretaceous, Eocene, Oligocene sandstones

Upper Cretaceous shales

Oligocene and Miocene shales

Gas, condensate and light oil

Trap-charge timing, reservoir integrity

A series of antiformal structures are preserved beneath the overridden Serrania del Interior (Blin, et. al., 1988) (Figure 15). The stripe where the alochtonous terraines are less than $3 \mathrm{~km}$ in thickness is targetable for the search of gas, oil and condensate accumulations. All the charged traps could have the potential risk of thermal cracking as it is observed in the Yucal Placer area (Figure 14) due to a high heat flow in the northern Central Guarico Basin. The reason of this change remains unexplained, but could lead to a gradient in hydrocarbon distribution away from that heat anomaly. The transition to the south from gas to liquid in northern Guarico is abrupt and can be narrowed to a distance of less than $8 \mathrm{~km}$. The sizes of the structures are such that they could hold a giant accumulation, however the integrity of proven reservoirs to the south is debatable.

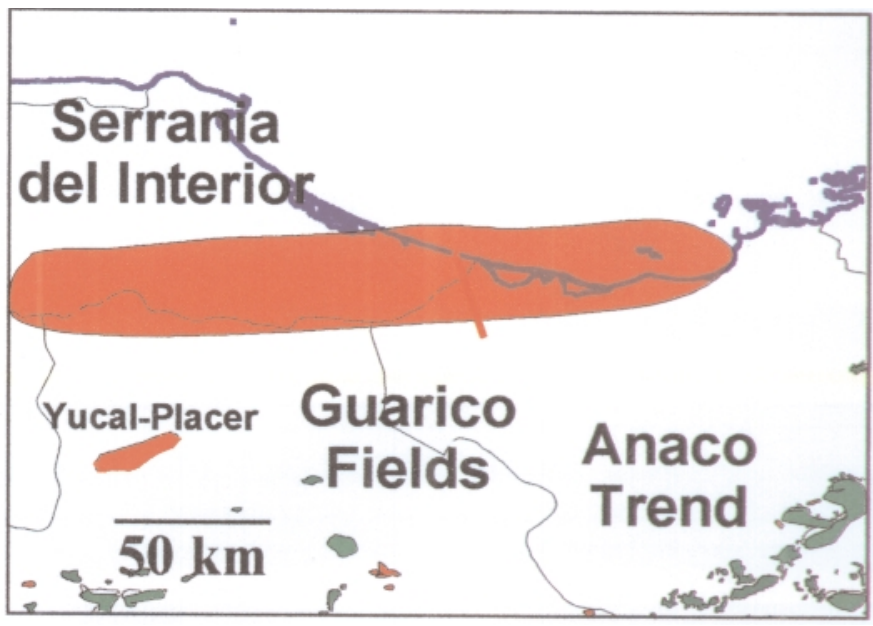

Figure 14. Location of Seismic Line (4)

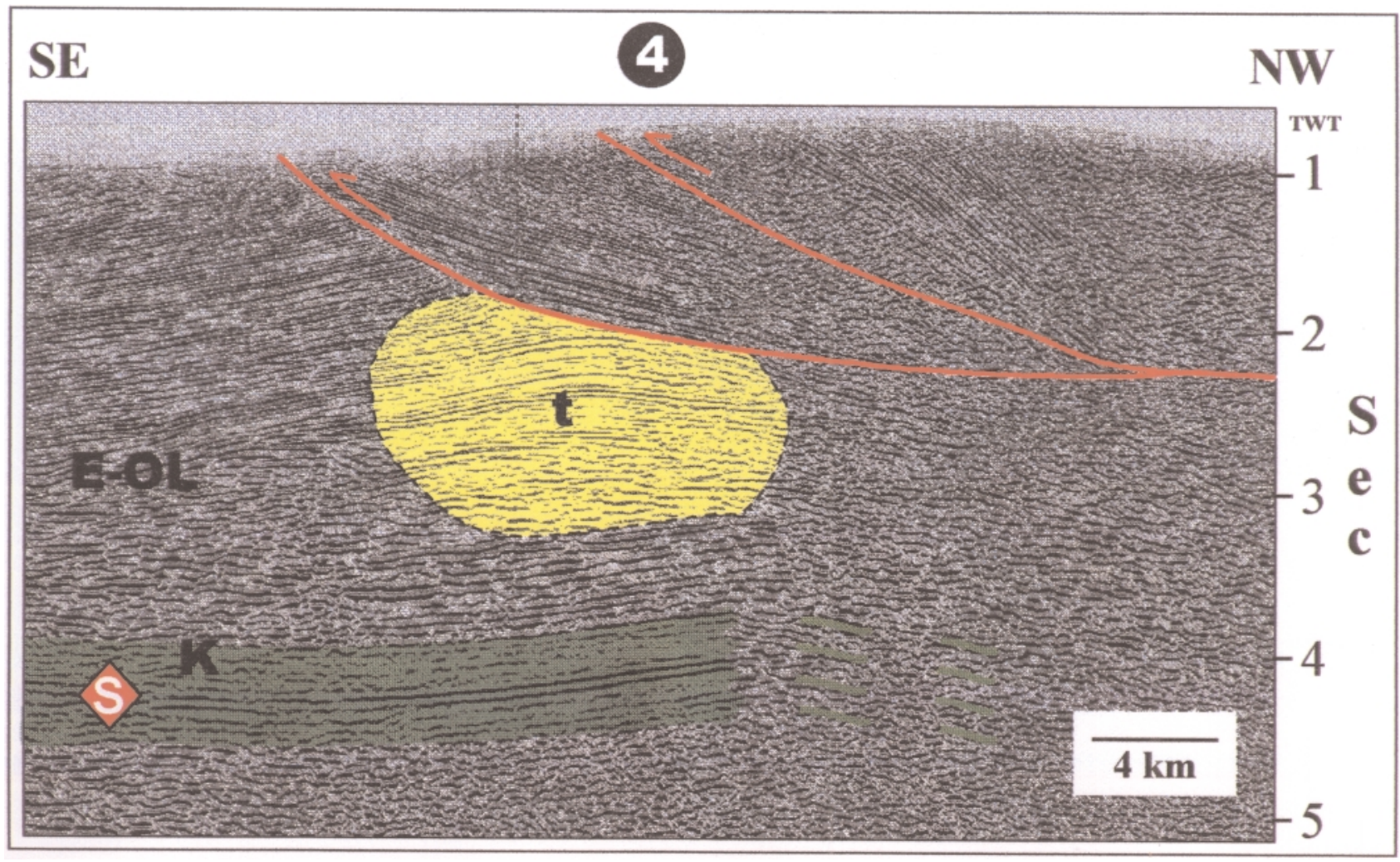

Figure 15. Subthrusted structural highs with Eocene-Oligocene sandstones as the main targets. $\mathrm{K}=$ Cretaceous, E-OL=Eocene to Oligocene; $S=$ Source rock; $t=$ Trap; Red arrow=Reverse fault. 


\section{ANACO TREND SOUTH SUBTHRUST (5)}

Area $\left(\mathrm{km}^{2}\right)$ :

Wildcats drilled

Number of Discoveries

Type of Traps

Main Reservoirs

Hydrocarbon System

Hydrocarbon Type

Critical Aspects
300-500 (Figure 16)

2

2

Hanging wall of inverted graben-Subthrust

Cretaceous, Oligocene to Miocene Sandstones

Upper Cretaceous shales

Oligocene and Miocene shales

Gas, condensates and light oil

Reservoir quality

The Anaco trend has been drilled since the thirties but only two wells have penetrated the subthrust, which happens to have oil-bearing sandstones. Oligocene and Miocene sandstones constitute the reservoirs in the hanging wall of the inverted graben in existence since the Cretaceous (Figure 17) (Murany, 1972).

The very prolific Anaco trend was consistently drained from the inverted foot wall, but exploration along the hanging wall has been restricted to two wells cutting across the main fault plane. On the other hand, there are a series of fields associated with the Greater Oficina play located to the south and very close to the Anaco trend. The transition between previously mentioned styles and the Oficina trend is presently unexplored and wells show clear evidences of it being productive.

If we assume an areal richness similar for this area as that found in surrounding areas, we are facing magnitudes well beyond the range of a Giant field.

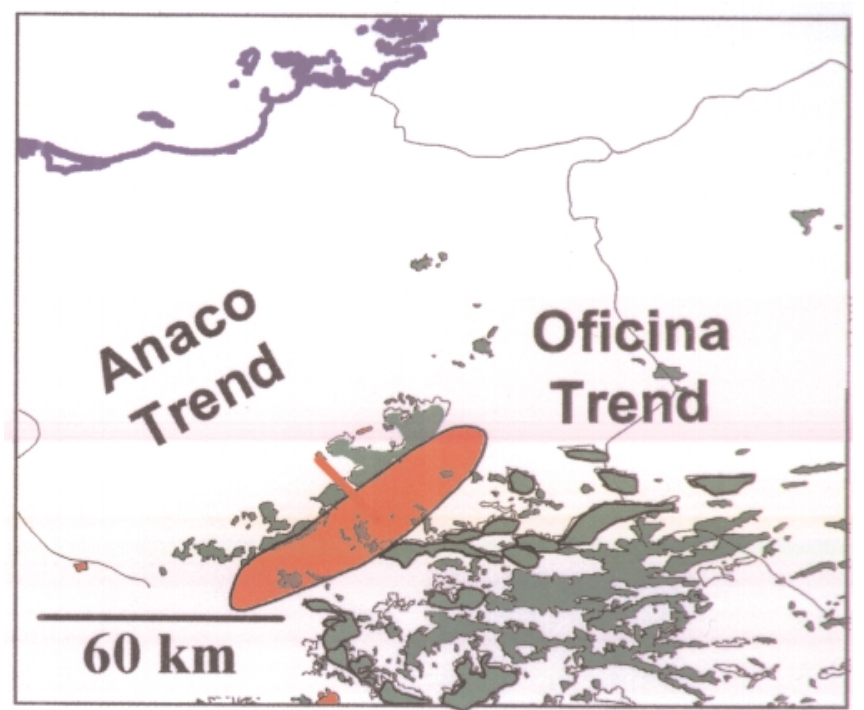

Figure 16. Location of Seismic Line (5)

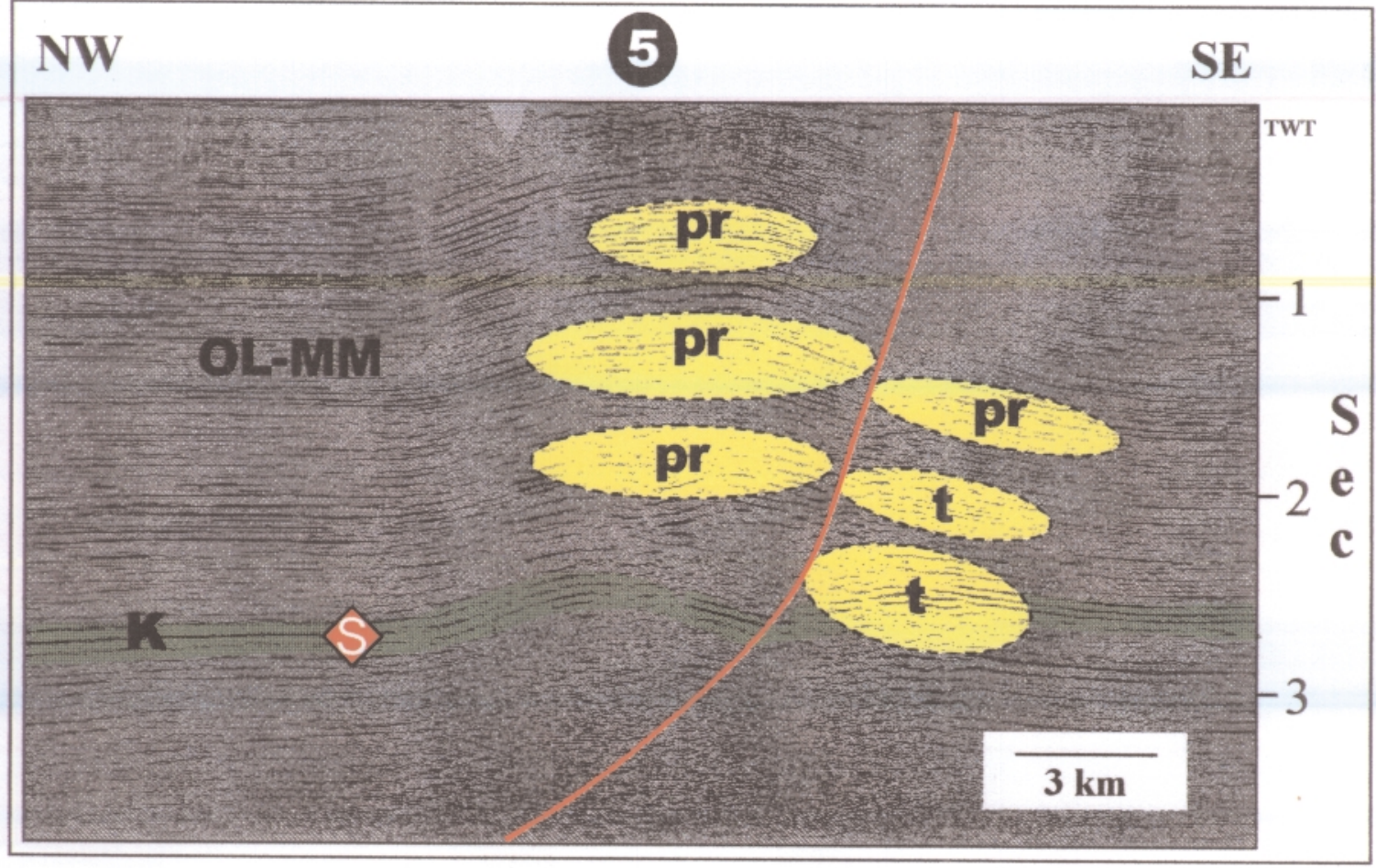

Figure 17. Acquisition of 3D seismic surveys currently in progress will allow to map the hanging wall of the Anaco trend, where Cretaceous (K) to Oligo-Middle Miocene (OL-MM) reservoirs can hold giant accumulations of gas, condensates and light oil. $\mathrm{S}=$ Source; $\mathrm{t}=$ Trap; $\mathrm{pr}=$ Proven reservoir. 
Area $\left(\mathrm{km}^{2}\right)$ :

Wildcats drilled

Number of Discoveries

Type of Traps

Main reservoirs and seals

Hydrocarbon System

Hydrocarbon Type

Critical Aspects
10000-18000 (Figure 18)

2 deep wells

None

Remigrated oil in partially inverted normal fault setting; onlaps and toplaps

Paleozoic, Triassic to Jurassic and Cretaceous sandstones

Triassic to Jurassic lacustrine shales

Silurian-Devonian source beds

Light oil

Reservoir integrity for Paleozoic reservoirs, Source rock richness

A major Mesozoic halfgraben system cuts transversally the Eastern and the Barinas Basins. The width of this system ranges between 20 to $35 \mathrm{~km}$ and extends over $500 \mathrm{~km}$ in length. The level of erosion and inversion is relatively low, but is certainly associated with tilted blocks rotated during the extensional phase (Figure 19). The graben infills and rotated sedimentary units are located at depths less than $2 \mathrm{~km}$. (Feo Codecido, et. al., 1984). This fact allows us to predict favorable reservoir characteristics so as to host potential giants in this elongated trend. The largest oil accumulation of the world (Orinoco Oil Belt) is located just above and south of this trend where part of the extra heavy oil could be derived from potential source beds found in this structural system.

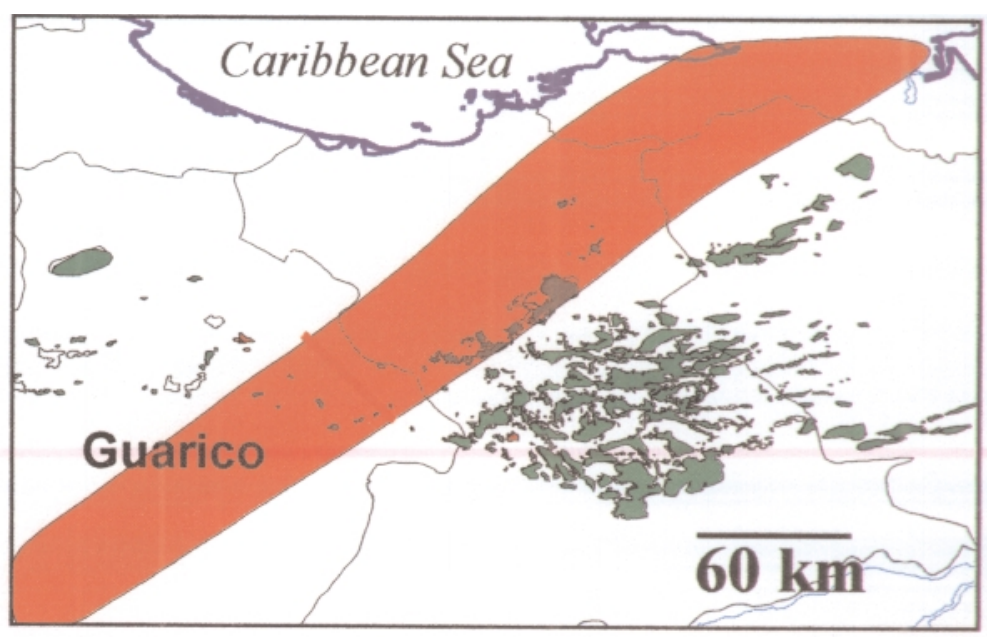

Figure 18. Location of Seismic Line (6)

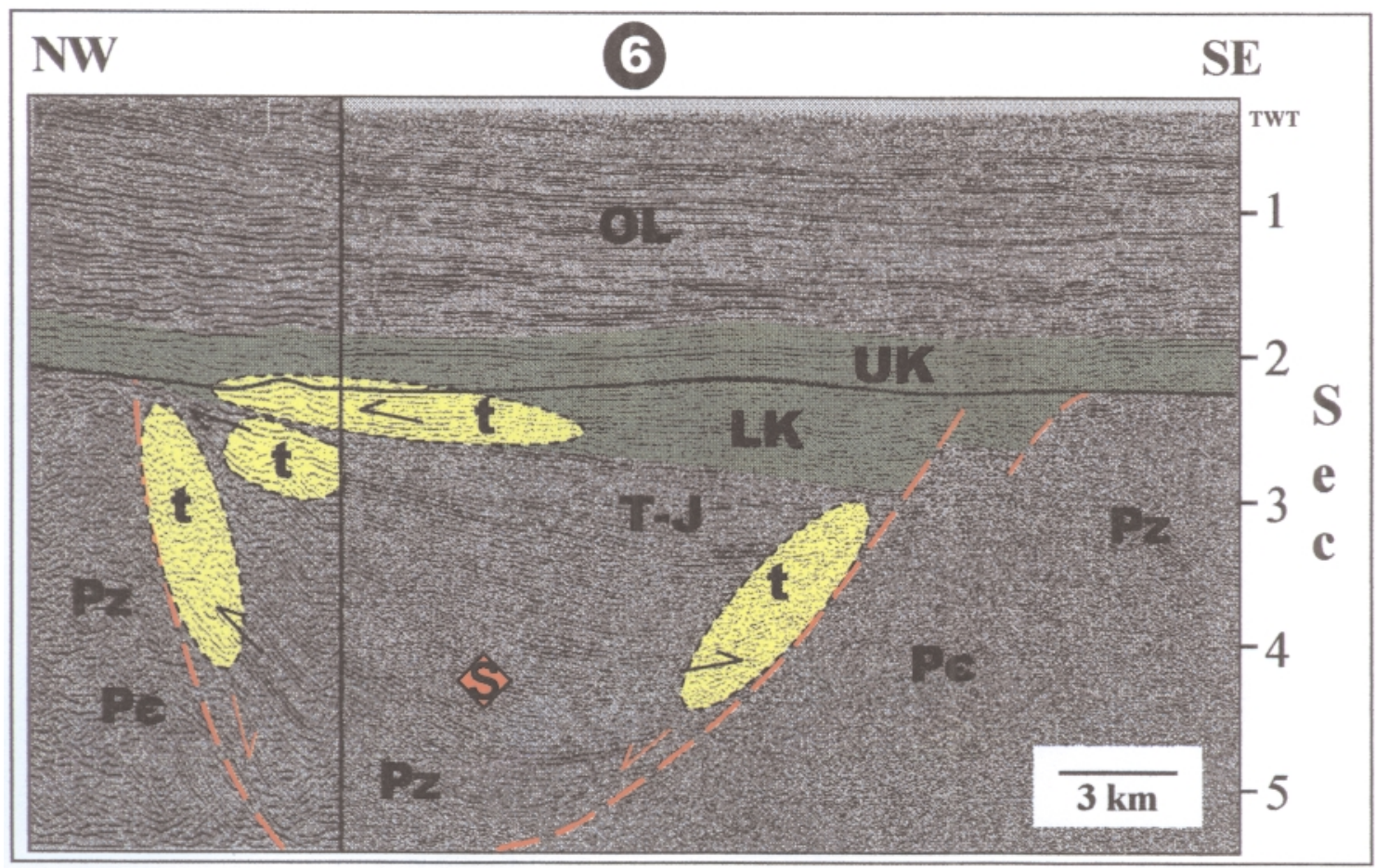

Figure 19. Onlaps against Pre-Cambrian and Paleozoic Basement and subunconformity toplaps constitute the main traps.

$\mathrm{PC}=$ Precambrian; PZ=Paleozoic; $\mathrm{T}-$ $\mathrm{J}=$ Triassic to Jurassic; LK=Lower Cretaceous; $\mathrm{UK}=\mathrm{Upper}$ Cretaceous; OL=Oligocene; $\mathrm{S}=$ Source rock; $\mathrm{t}=$ Trap; Black arrow=Onlap; Red arrow=Normal fault. 


\section{NORTHANDEAN MOUNTAIN FRONT (7)}

Area $\left(\mathrm{km}^{2}\right)$ :

Wildcats drilled

Number of Discoveries

Type of Traps

Main Reservoirs

Hydrocarbon System

Hydrocarbon Type

Critical Aspects
3000-5000 (Figure 20)

4

1

Thrusts and backthrusts in triangle zones

Cretaceous

Upper Cretaceous calcareous shales, Paleogene carbonaceous shales

Light oil, condensate and gas

Reservoir depths

Large key imbricate thrusts are juxtaposed in triangle zones aligned along the northern front of the Merida Andes (Figure 21). At least four thrust sheets combining the La Luna source beds are interpreted from good quality seismic profiles. The reservoirs are usually sandstones under the La Luna beds, but the overlying lower Tertiary could also become a potential reservoir when the triangle zones have been disactivated and are cross-cutt by deeper thrusts. All of these independent structures are potential giant fields.

At least fifty active oil seeps are located along the roof thrust defined by the Colon shales, above the $\mathrm{La}$ Luna Formation. These seepages have been mapped along the northern flank of the Andes at elevations ranging from sea level to $3000 \mathrm{~m}\left(9000^{\prime}\right)$.

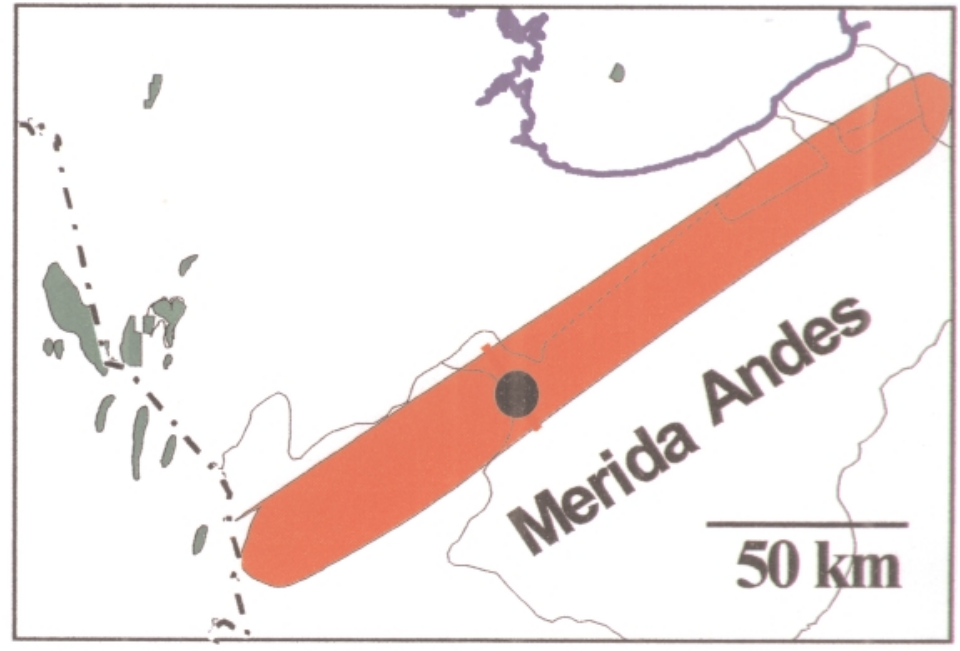

Figure 20. Location of Seismic Line (7)

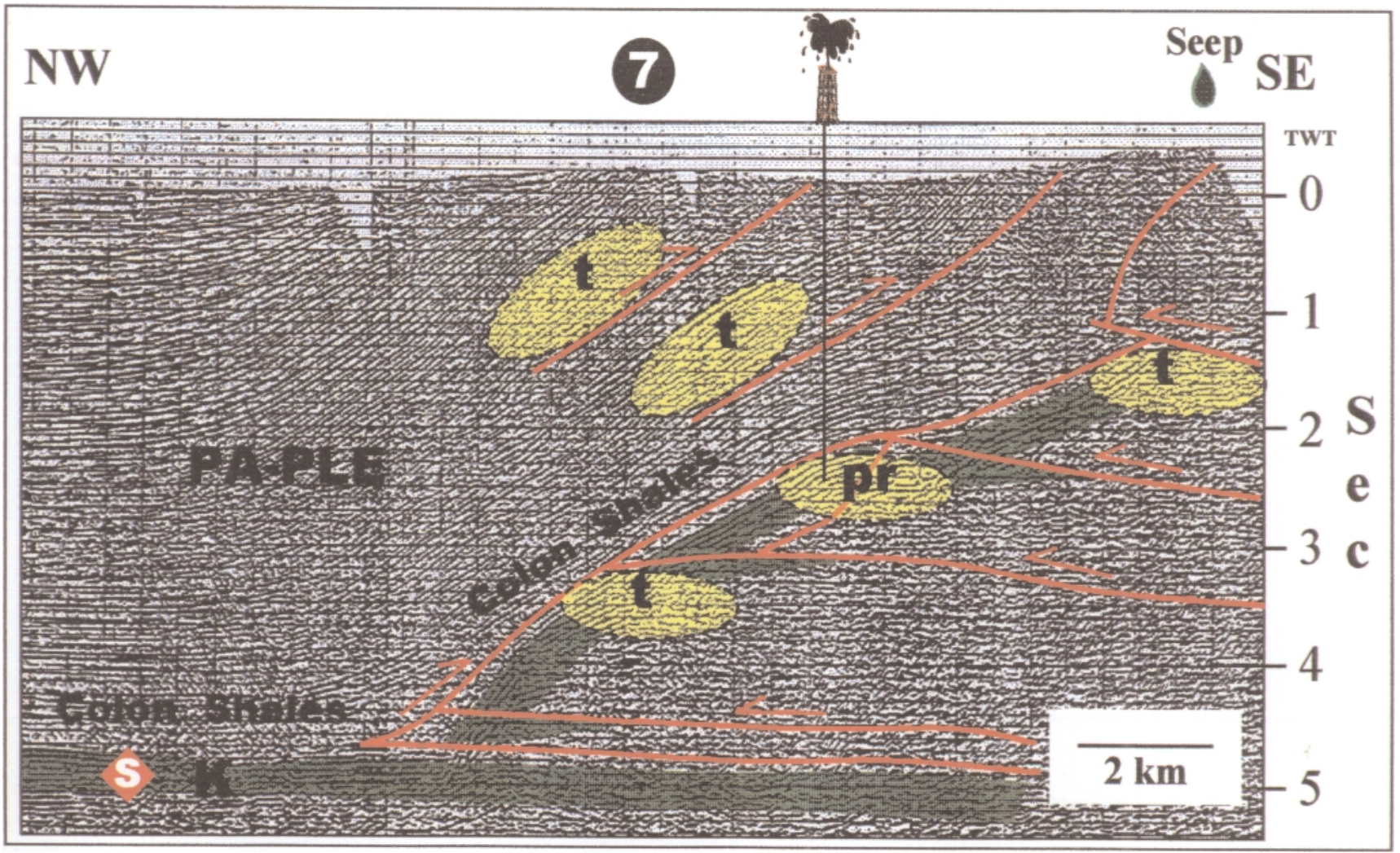

Figure 21. Imbricated thrusts in a triangle zone that has been successfully proven by a well. $\mathrm{K}=\mathrm{Cretaceous}$; PA-PLE=Paleocene to Pleistocene; $S=$ Source; $t=T r a p ;$ pr=Proven reservoir; Red arrow=Reverse fault. 


\section{SOUTHANDEAN MOUNTAIN FRONT (8)}

Area $\left(\mathrm{km}^{2}\right)$ :

Wildcats drilled

Number of Discoveries

Type of Traps

Main Reservoirs

Hydrocarbon System

Hydrocarbon Type

Critical Aspects
5000 (Figure 22)

2

None

Anticlines due to thrusting verging to north

Cretaceous calcareous sandstones

Eocene to Oligocene sandstones

Upper Cretaceous calcareous shales

Gas and Light oil

Charge due to remigration

This play is the result of the emplacement to the south of the Eocene foredeep related to the evolution of the Lara Nappe accretionary prism, where most of the oil was forced to migrate southeastward towards the Guyana Shield. Most of the important traps were originally half grabens developed on the inner segments of the Cretaceous passive margin. Most of the half grabens are post Cretaceous but occurred before the Pre-Eocene compression.

Some of them were partially reactivated during the Tertiary, but this effect was certainly more pronounced during the north vergent Pliocene Andean compression. This later event was responsible for creating the diversity of traps distributed along this front. The folded structures reached several kilometers in length and approximately $3 \mathrm{~km}$ in width.

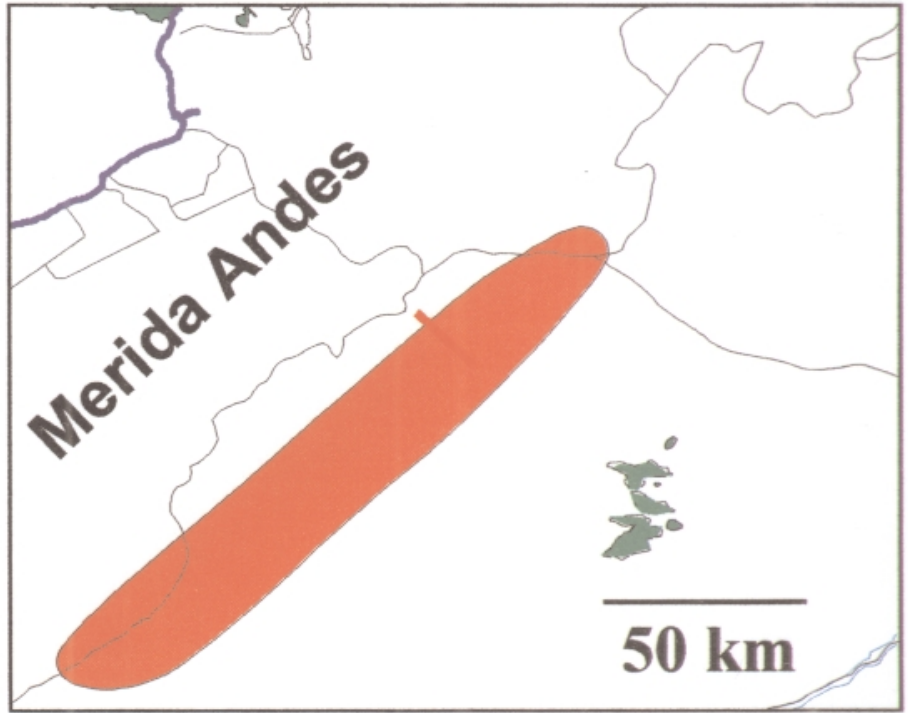

Figure 22. Location of Seismic Line (8)

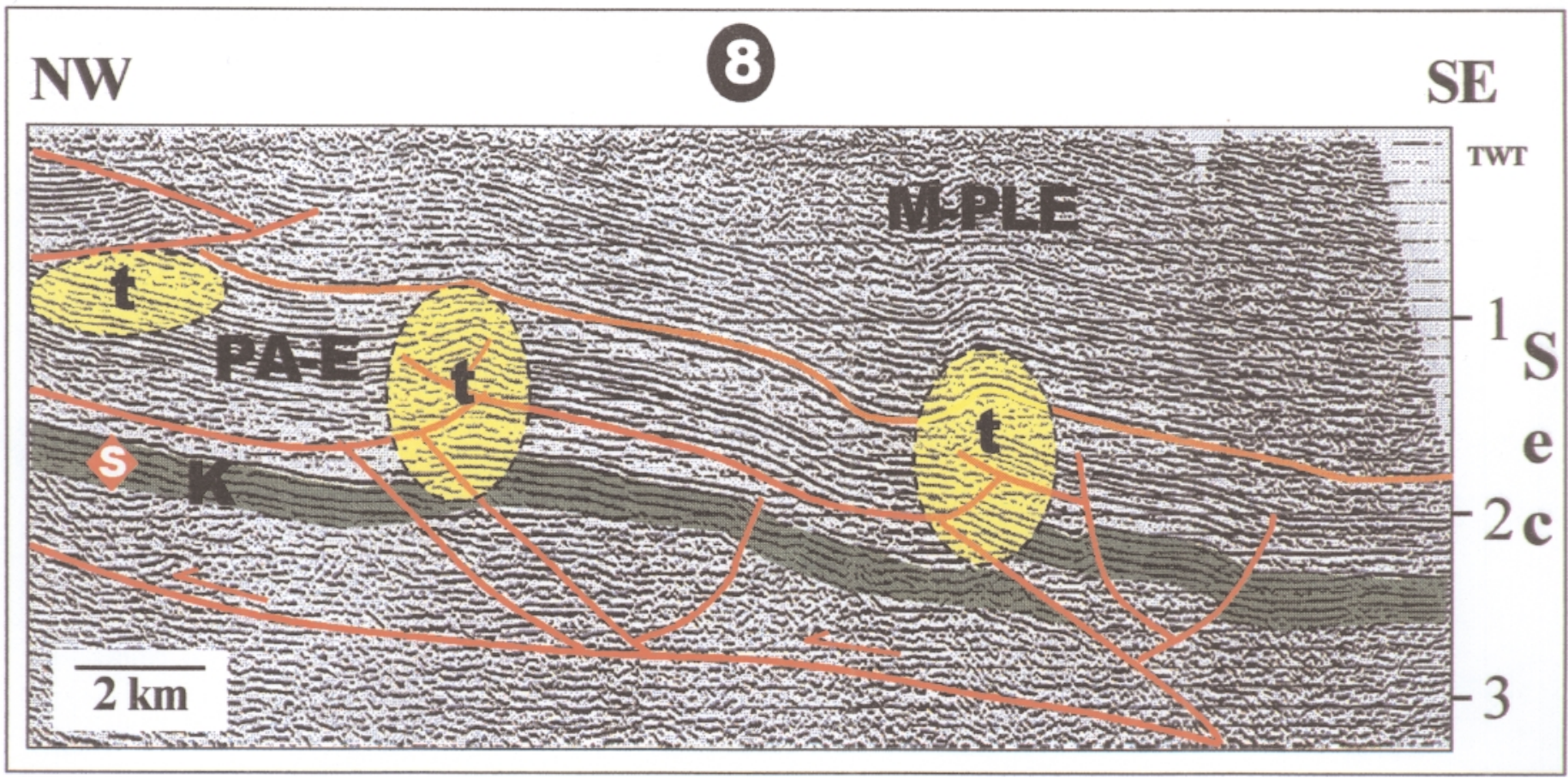

Figure 23. Main targets are anticlines associated to north verging thrusts that occurred during the Andean deformation. $\mathrm{K}=$ Cretaceous; $\mathrm{PA}-\mathrm{E}=\mathrm{Paleocene}$ to Eocene; $\mathrm{M}-\mathrm{PLE}=$ Miocene to Pleistocene; $\mathrm{t}=\mathrm{Trap}$; $\mathrm{S}=$ Source rocks 


\section{BARINAS-APURE STRATIGRAPHIC TRAPS (9)}

Area $\left(\mathrm{km}^{2}\right)$ :

Wildcats drilled

Number of Discoveries

Type of Traps

Main Reservoirs

Hydrocarbon System

Hydrocarbon Type

Critical Aspects
2000-2500 (Figure 24)

None targeting these plays

At least two while drilling structural traps

Onlaps, subunconformity truncations, and prograding sandstones

Cretaceous calcareous sandstones

Paleocene to Eocene sandstones

Upper Cretaceous calcareous shales

Light oil and associated gas

Mapping of trap and lateral seal

The variety of stratigraphic combinations that create traps in this area are: onlap of Paleocene to Eocene sandstones on Cretaceous Shales, Cretaceous sandstones interbedded with shales subcropping below Oligocene Shales, Upper Eocene to Oligo-Miocene sandstones onlapping on Cambrian to Precambrian rocks and Upper Cretaceous deltaic sandstones prograding to the north (Figure 25). It is suspected that wells that have drilled to test structural traps tested some of these concepts, such as the ones in the Arauca field in Colombia and La Victoria field in Venezuela. The first one produced light oil and gas from the Cretaceous porous calcareous sandstones, Paleocene and Eocene sandstones onlapping the Cretaceous shales and pinchout of Upper Eocene to Oligocene sandstones (Urbina, C., 1999, personal communication).

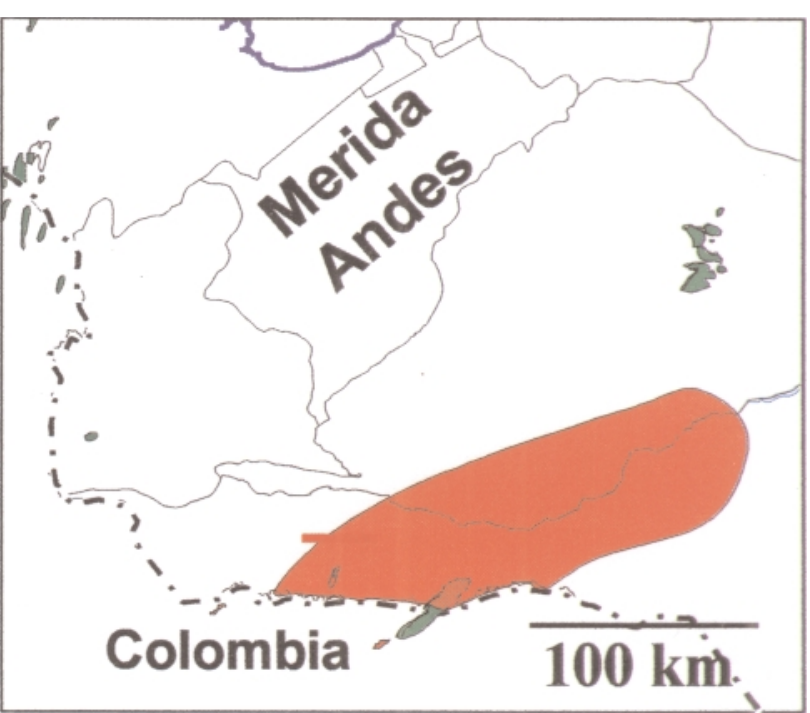

Figure 24. Location of Seismic Line (9)

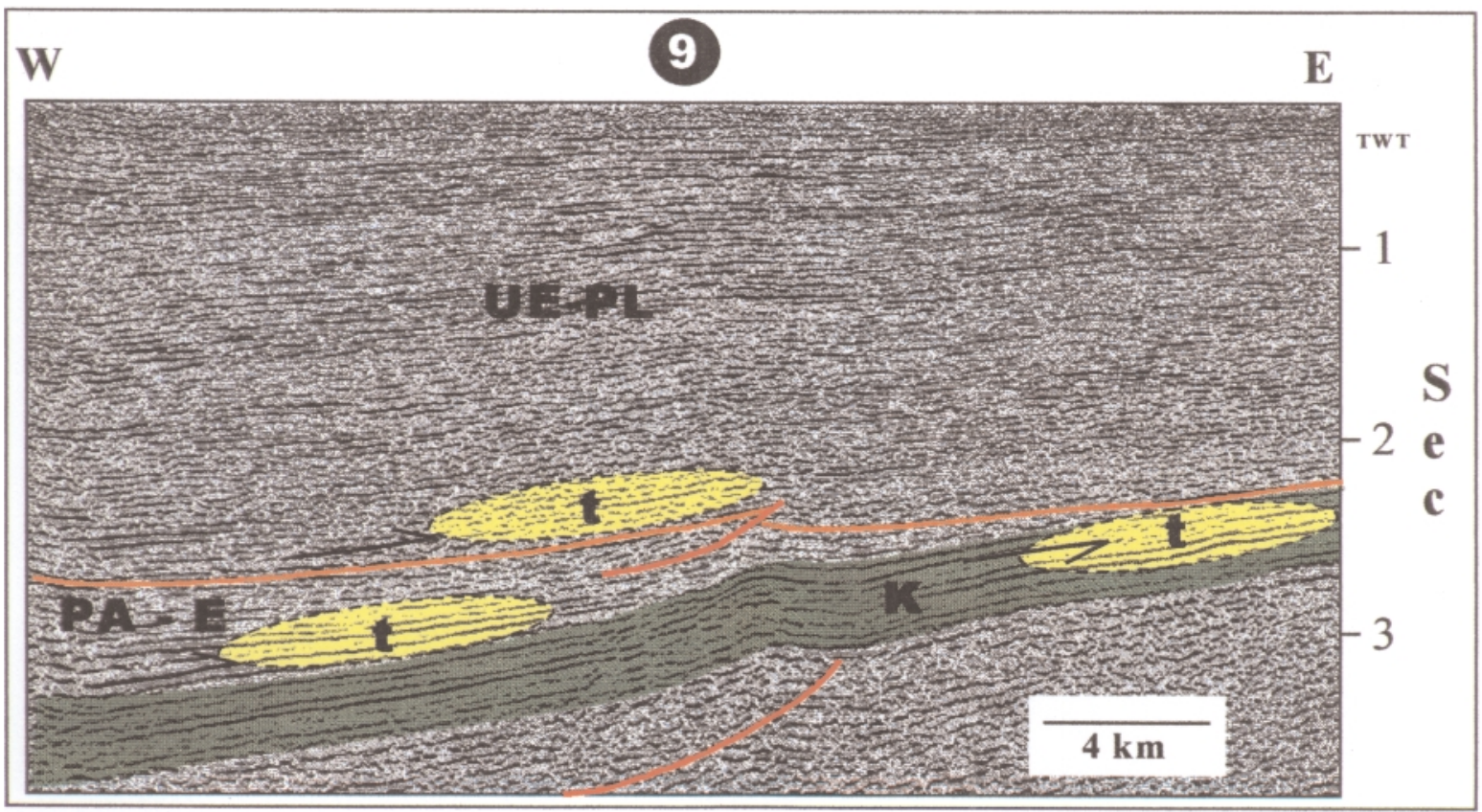

Figure 25. Onlaps and subunconformity traps resembling the shallow depth Orinoco Oil Belt stratraps but filled with light oil, because they are at a greater depth and protected from bacterial influence. $\mathrm{K}=$ Cretaceous; PA-E=Paleocene to Eocene; UE-PL=Upper Eocene to Pliocene; $t=$ Trap; Black arrow=Onlap and truncation. 


\section{PRECRETACEOUS WEATHERED ZONE (10)}

Area $\left(\mathrm{km}^{2}\right)$ :

Wildcats drilled

Number of Discoveries

Type of Traps

Main Reservoirs

Hydrocarbon Systems

Hydrocarbon Type

Critical Aspects
Unknown (Figure 26)

Unknown

Totumo, Rio de Oro, La Paz, and Mara Fields

Stratigraphic

Weathered-Fractured zone

Silurian-Devonian calcareous shales

Triassic-Jurassic shales

Light to medium oil

Source rock, Lateral seal, Target depths

These peculiar traps associated with an unconformable surface were developed during a very extensive period of time. In this case they are thought to be part of the peneplained surfaces underlying the pre-rift unconformity of the Tethyan passive margin (Figure 27). They formed as chemical weathering of the clastic cements or partial destruction of meta-sediments. They have been associated with fractured reservoirs (Smith, 1956). A good example of this play are the basement reservoirs of the giant La Paz and Mara fields, and the very old Totumo field from northwestern Maracaibo Basin. Here appreciable quantities of hydrocarbons have been produced. These plays could be evaluated in similar circumstances in the Barinas Basin as well as along the belt corresponding to the inner segment of the Paleozoic foredeep that encroached on the Guayana Shield, at depths less than $3000 \mathrm{~m}(9000 \mathrm{ft})$.

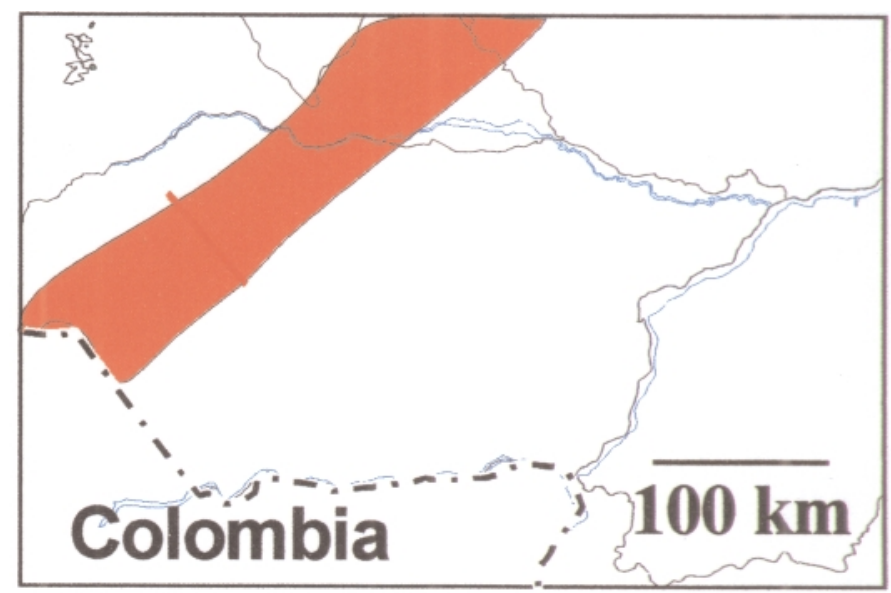

Figure 26. Location of Seismic Line (10)

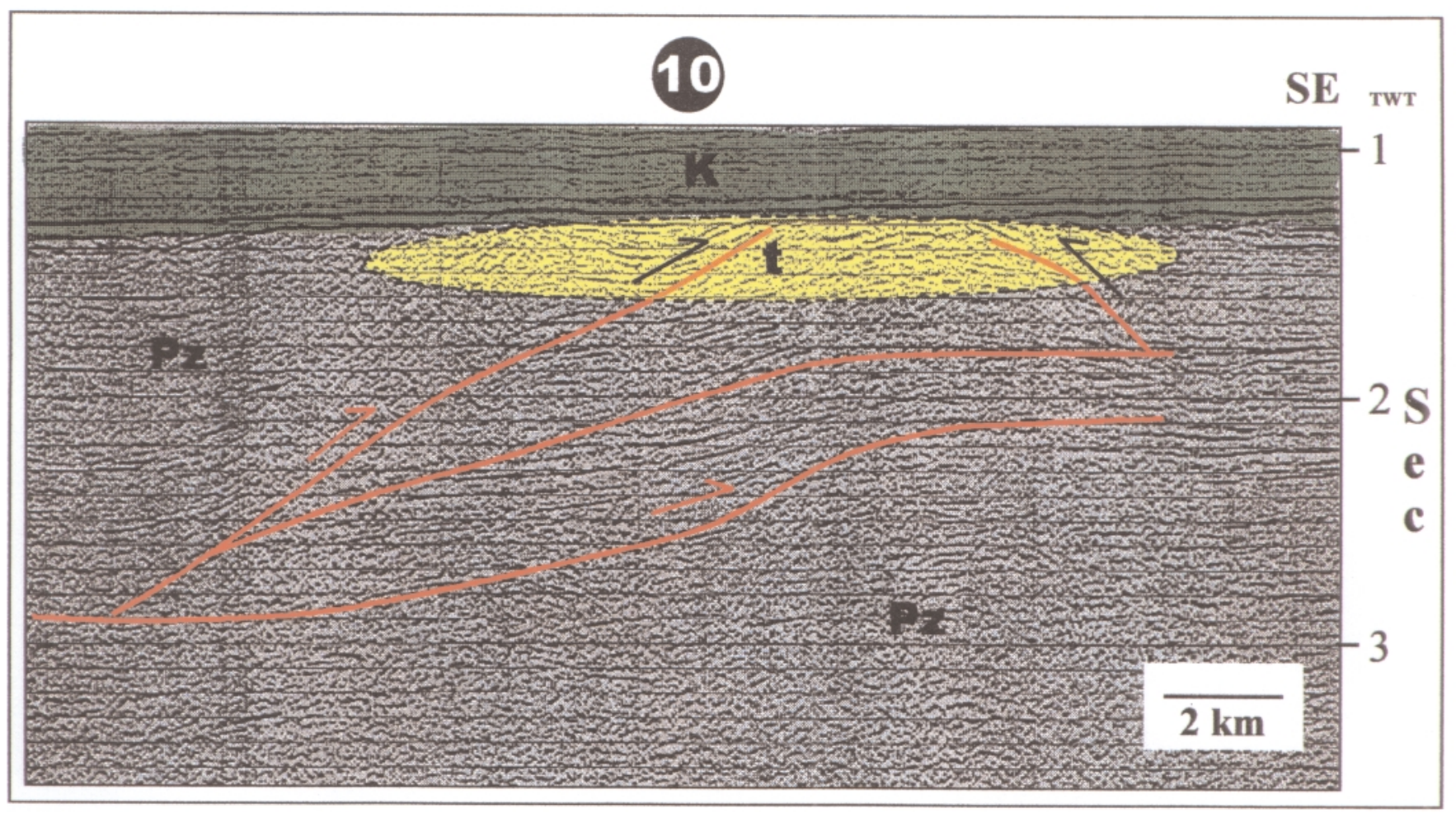

Figure 27. Deformation front of the Paleozoic Orogen. Long exposure of Paleozoic beds before the sedimentation of Cretaceous intervals enhanced porosity and permeability of the subunconformity layers. $\mathrm{PZ}=$ Paleozoic; $\mathrm{K}=$ Cretaceous; $\mathrm{t}=$ trap; Red arrow=Reverse fault. 


\section{NORTHERN OFFSHORE VENEZUELA BASIN (11)}

Area $\left(\mathrm{km}^{2}\right)$ :

Wildcats drilled

Number of Discoveries

Type of Traps

Main Reservoirs

Hydrocarbon System

Hydrocarbon Type

Critical Aspects
30000-40000 (Spreading out in four places along Venezuela Offshore) (Figure 28)

Approximately 50 offshore and 50 onshore, concentrated in four areas Six fields onshore and eight offshore

Rotated normal faulted blocks, Inverted grabens, Pinchouts

Paleogene to Miocene turbiditic to deltaic sandstones and Mesozoic

Metamorphic Basement

Eocene to Middle Miocene shales

Light oil, condensates and gas

Reservoir presence and quality as well as probably oil charge limitation

The most important type of trap in the northern Venezuela offshore Basins are the Upper Early Miocene to Middle Miocene inversion anticlines (Figure 29) (Audemard, 1991; Macellari, 1995). This kind of trap is the product of the reactivation of the Paleogene to Early Miocene half graben system due to Neogene transpression. It implies the folding of the Paleogene to Early Miocene section, which contains several discrete deep marine sandstones interbedded with shales that constitute internal seals. They segment the hydrocarbon accumulations into separate compartments; each one could have its own gasoil-water contacts and its own pressure distribution. In this type of play, fracture zones and faulting systems associated with the Paleogene extension could represent the main migration pathways for the Paleogene or Middle Miocene source beds (Ysaccis, 1997).

Positive results have already been reported from the drilling of an inversion structure to the northwest of Tortuga Island. A well located on the flank of that anticline encountered $43^{\circ}$ API oil in Early Miocene reservoirs.

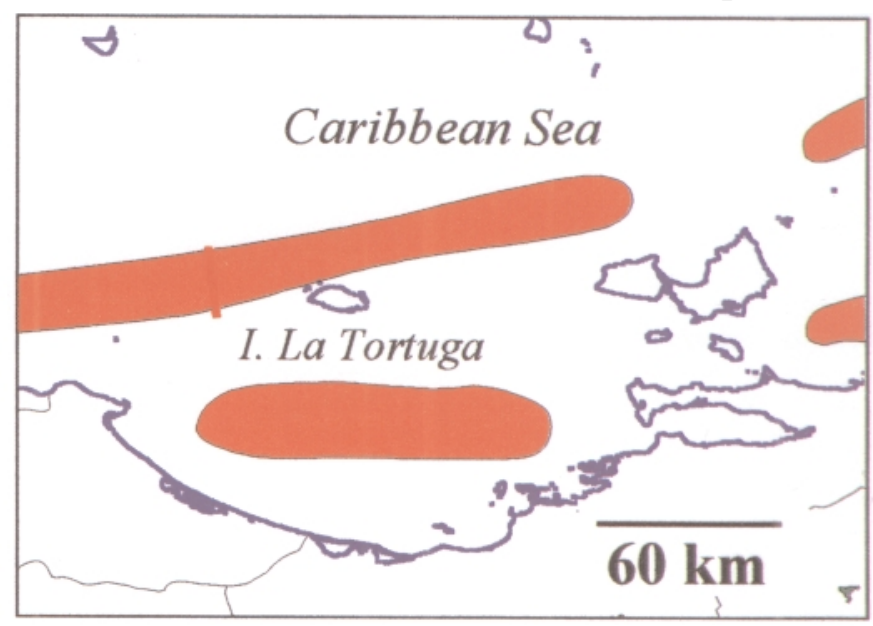

Figure 28. Location of Seismic Line (11)

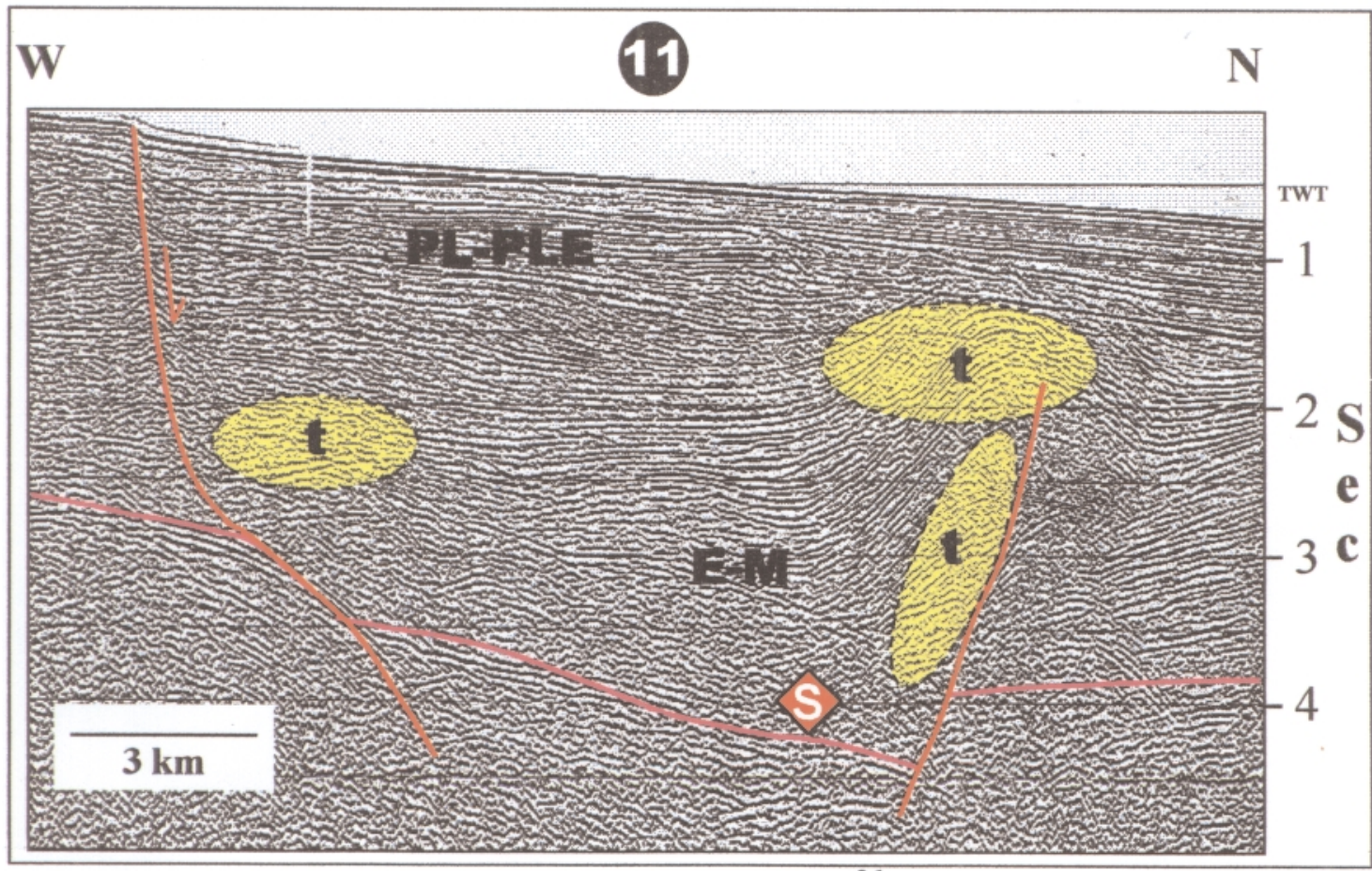

Figure 29. Typical image of an offshore rift basin associated to the evolution of the active margin. An Eocene (E) to Pleistocene (PLE) section fills the basin. Main Source rocks (S) are in the lowermost section. Traps (t) are rotated normal faulted blocks, inverted grabens and pinchouts. 


\section{SUMMARY}

Eleven underexplored provinces can hold potential giant fields (Figures 30 and 31). These provinces range from extensive weathered Paleozoic basement in the west of the country to, still little known thick TriassicJurassic grabens, and Pleistocene deep-water sandstones offshore and in the Eastern Venezuelan Basin. A variety of structural and stratigraphic traps, comprising continental to deep-water sandstones, local shallow water carbonates, are present in these provinces.

A double setting of Paleozoic and Mesozoic-Cenozoic active and passive margins favored the sedimentation of two main source rocks, Silurian-Devonian and Upper Cretaceous calcareous shales, that matured through time. Additionally, Tertiary source rocks are present in the rift basins and foredeeps.

Gas and light oil accumulations prevailed in the northern part and east of Venezuela; and they grade to medium and then to heavy oil towards the Guyana Shield.

Venezuela has a new variety of drillable exploration opportunities for the next millenium.

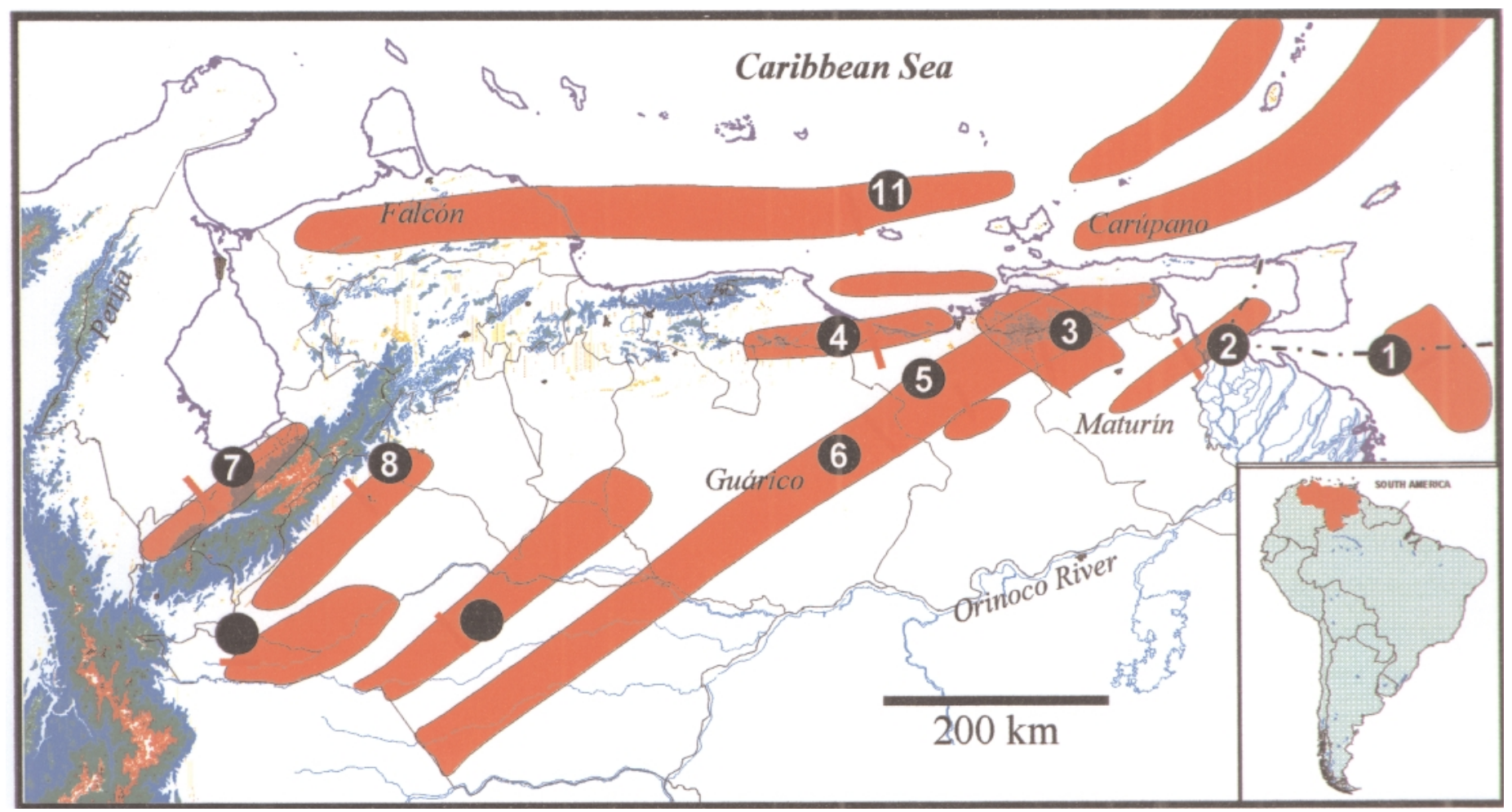

Figure 30. Future Petroliferous Provinces of Venezuela.

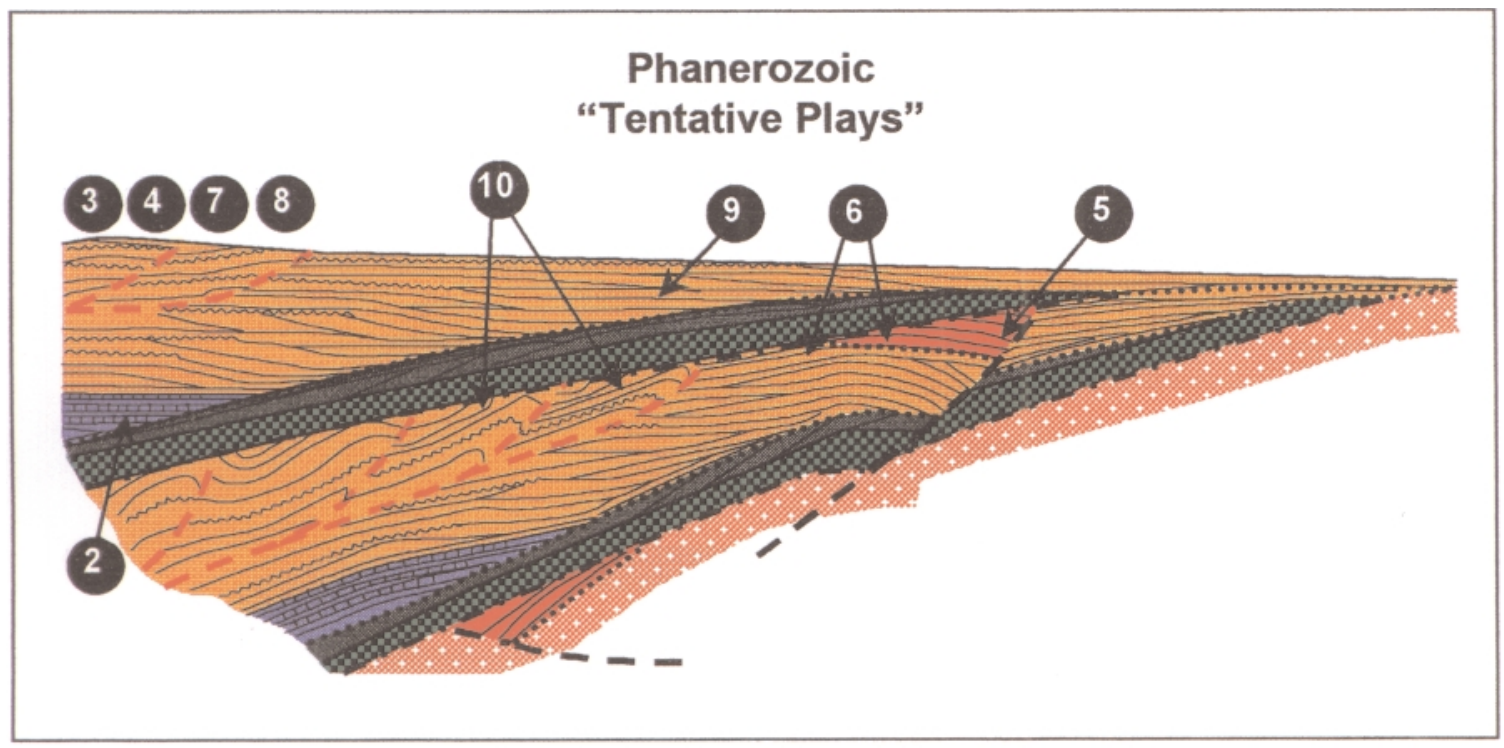

Figure 31.

Schematic crosssection showing possible plays. Numbers correspond to the provinces indicated in Figure 30. 


\section{SELECTED REFERENCES}

Audemard, F.E., 1991, Tectonics of Western Venezuela, (Ph.D. Thesis) Rice University, Houston, Texas, 245 p. and 64 foldouts.

Audemard, F.E., Audemard, N., Rodríguez, E., and Jordán, N., 1993, Generation and Migration of Heavy Oil from Guárico and Southwestern Maturín Sub-Basins, AAPG Bull. Tulsa, V. 77 (3), p. 304.

Audemard, F.E., and Lugo, J., 1996, Petroleum Geology of Venezuela, Caracas, II AAPG/SVG International Conference, (course notes), $320 \mathrm{p}$.

Audemard, F.E., Cabrera, E., Di Croce, J., and Melendez, A., 1997, Sinopsis de la Geología de Venezuela, in Léxico Estratigráfico de Venezuela, III Edition, Vol. I, Caracas, p. 18-28.

Aymard, R., Pimentel, L., Eitz, P., López, P., Chaouch, A., Navarro, J., Mijares, J., and Pereira, J.G., 1990, Geological Integration and Evaluation of Northern Monagas, Eastern Venezuelan Basin: in Brooks, J., (Ed.) Classic Petroleum Provinces; Geol. Soc. London, Blackwell, Sp. Pub. N 50., P. 37-53.

Bally, A. W., 1989, Phanerozoic Basins of North America, in Bally, A.W., and Palmer, A.R., eds., The Geology of North America-An overview: Boulder, Colorado, Geological Society of America, The Geology of North America, V.A., p. 397-446.

Bartok, P., 1993, Prebreakup Geology of the Gulf of México-Caribbean: Its relation to Triassic and Jurassic Rift Systems of the Region, Tectonics, Vol. 12, $\mathrm{N}^{\circ}$ 2, p. 441-559.

Blaser, R., White, C., 1984, Source Rock and Carbonization Study, Maracaibo Basin, Venezuela; AAPG, Tulsa, mem 35, p. 229-254

Blin, B., Cabrera, E., Stephan, J.F., and Beck, C., 1988, Estructura del Frente de Montañas de la Cadena Caribe Occidental al Este de Guarumen-Venezuela; IV Venezuelan Geophysical Cong., Caracas, p. 457-466.

Boesi, T.,and Goddard, D., 1991, A New Geologic Model Related to the Distribution of Hydrocarbon Source Rocks in the Falcón Basin, Northwestern Venezuela, in K. T. Biddle, (ed.), Active Margins: AAPG, Tulsa, Mem 18(48),p. 303-319.

Chigne, N., and Hernández, L., 1993, Guafita Field, Barinas-Apure Basin, Apure State, Venezuela: in N.H. Foster, and E.A. Beaumont, (Eds.), Structural traps VIII, AAPG Treatise of Petroleum Geology, p. 231-250.

Di Croce, J., 1995, Eastern Venezuela Basin: Sequence Stratigraphy and Structural Evolution; Rice University (Ph.D. Thesis), Houston, Texas, 225 p.

Duval, B., Cramez, C., and Valdez, G., 1994, Campos Gigantes de Finales de los 80 Asociados con Subduccion Tipo A en Suramerica; Bull., Soc. Venez. Geol., v. 19 (1-2), p. 20-40.

Erlich, R.N., and Barrett, S.F., 1992, Petroleum Geology of the Eastern Venezuela Foreland Basin: in R.W. Macqueen, and D.A. Leckie, (Eds), Foreland Basins and Folded Belts; AAPG Memoir 55, Tulsa, p. 341-362.

Feo-Codecido, G., Smith Jr., F.D., Aboud, N., and Di Giacomo, E., 1984, Basement and Paleozoic Rocks of the Venezuelan Llanos Basin, in W.E. Bonini, R. B. Hargraves, and R. Shagam, (Eds.), The CaribbeanSouth American Plate Boundary and Regional Tectonics; Boulder, Colorado, GSA, Mem. 162, p. 175-188. 
Hedberg, H.D., 1931, Cretaceous Limestones as Petroleum Source Rocks in Northwestern Venezuela; AAPG Bull., Tulsa, v.15 (3), p. 229-244.

Hedberg, H.D., 1950, Geology of the Eastern Venezuela Basin (Anzoátegui, Monagas-Sucre-eastern Guárico portion). Geol. Soc. Amer., Bull., Vol. 61, N 11, p. 1.173-1.216.

Hung, E.J., 1997 Foredeep and Thrust Belt Interpretation of the Maturin sub-basin, Eastern Venezuela Basin (Master of Arts Thesis); Houston, Rice University, 125 p.

James, K., 1985, Marco Tectónico, Estilos Estructurales y Habitat de los Hidrocarburos Cretácicos, Venezuela; VI Venezuelan Geol. Cong., Caracas, p. 2452-2469.

Lugo, J., 1991, Cretaceous to Neogene Tectonic Control on Sedimentation: Maracaibo Basin, Venezuela: (Ph.D. Thesis) Univ. Texas at Austin, 219 p.

Lugo, J. and Audemard, F.E., 1996, The Venezuelan Foredeeps. Part I: Stratrigraphy; San Diego AAPG Annual Conf., p. A86.

Macellari, C.E., 1995, Cenozoic Sedimentation and Tectonics of the Southwestern Caribbean Pull-Apart Basin, Venezuela and Colombia, in Tankard, A. J., Suarez S., R., Welsink H.J., Petroleum basins of South America: AAPG Memoir 62, p. 757-780.

Martínez, A., 1995, Cronología del Petróleo Venezolano 1943-1993, VII reprint, Ediciones Cepet, Caracas, $462 \mathrm{p}$.

Mencher, E., Fitcher, H.J., Renz, H.H., Wallis, W.E., Renz, H.H., Patterson, J.M., and Robie, R.H., 1953, Geology of Venezuela and its Oil Fields; AAPG Bull., Tulsa, v.37 (4), p. 690-777.

Miller, J., Edwards, K.L., Wolcott, P.P., Anisgard, H.W., Martin, R., and Anderegg, H., 1958, Habitat of Oil in the Maracaibo Basin, Venezuela; AAPG Bull., Tulsa, v. 42 (3), p. 601-640.

Murany, E.E., 1972, Tectonic Basis for the Anaco Fault; AAPG Bull., V.56 (5), p. 860-870.

Parnaud F., Gou Y., Pascual J.-C., Truskowski, I., Gallango, O., Passalacqua, H., and Roure, F., 1995, Petroleum Geology of the Central Part of the Eastern Venezuelan Basin, in Tankard, A. J., Suarez S., R., Welsink; H. J., Petroleum Basins of South America: AAPG Memoir 62, p. 741-756.

Salvador, A., and Stainforth, R.M., 1968, Clues in Venezuela to the Geology of Trinidad and Vice-versa. IV Caribbean Geological Conference Trinidad 1965. p. 31-40.

Smith, J.E., 1956, Basement Reservoir of La Paz - Mara Oil Fields, Western Venezuela; AAPG Bull., Tulsa, v. 40 (2), p. 380-387.

Stephan, J.f., 1982, Evolution Géodynamique du Domaine Caraibe, Andes et Chaine Caraibe Sur la Transversale de Barquisimeto, Venezuela, (Thése d'etat), Université de Paris IV, 512 p.

Talukdar, S., Gallango, O., and Chin-A-Lien, M., 1986, Generation and Migration of the Hydrocarbons in the Maracaibo Basin, Venezuela: An Integrated Basin Study; Org. Geochemical, v. 10, p. 261-279.

Talukdar, S., and Marcano, F., 1994, Petroleum Systems of the Maracaibo Basin, Venezuela, in L.B. Magoon and W.G. Dow, (Eds.): The Petroleum System from Source to Trap: AAPG Memoir 60. Tulsa, p. 463-481. 
Ysaccis, R., 1997, Tertiary Evolution of the Northeastern Venezuela Offshore. (Ph.D. Thesis), Rice University, Houston, Texas, 285 p.

\section{ACKNOWLEDGEMENTS}

We highly appreciate permission granted for PDVSA Oil and Gas to publish this paper. Technical discussions with all of the colleagues of the PDVSA's Regional Exploration Study Team helped to unravel the realm of Venezuela hydrocarbon potential. Also we would like to thank Christopher White for his helpful suggestions and editing of this paper and the diligent response of our technical staff. 